
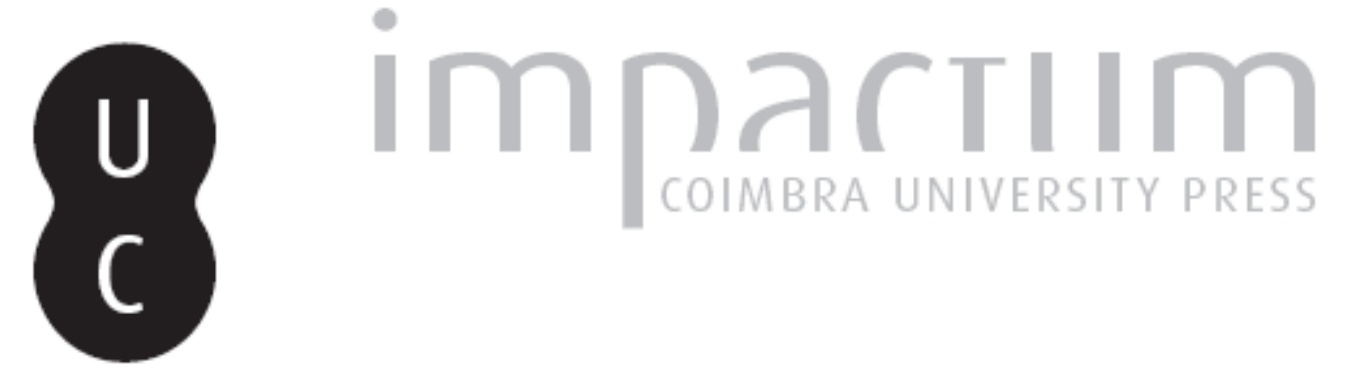

\title{
A paisagem rural romana e alto-medieval em Portugal
}

Autor(es): $\quad$ Alarcão, Jorge de

Publicado por: Imprensa da Universidade de Coimbra

URL persistente:

URI:http://hdl.handle.net/10316.2/45406

DOI:

DOI:https://dx.doi.org/10.14195/1647-8657_37_4

Accessed : $\quad$ 26-Apr-2023 16:29:55

A navegação consulta e descarregamento dos títulos inseridos nas Bibliotecas Digitais UC Digitalis, UC Pombalina e UC Impactum, pressupõem a aceitação plena e sem reservas dos Termos e Condições de Uso destas Bibliotecas Digitais, disponíveis em https://digitalis.uc.pt/pt-pt/termos.

Conforme exposto nos referidos Termos e Condições de Uso, o descarregamento de títulos de acesso restrito requer uma licença válida de autorização devendo o utilizador aceder ao(s) documento(s) a partir de um endereço de IP da instituição detentora da supramencionada licença.

Ao utilizador é apenas permitido o descarregamento para uso pessoal, pelo que o emprego do(s) título(s) descarregado(s) para outro fim, designadamente comercial, carece de autorização do respetivo autor ou editor da obra.

Na medida em que todas as obras da UC Digitalis se encontram protegidas pelo Código do Direito de Autor e Direitos Conexos e demais legislação aplicável, toda a cópia, parcial ou total, deste documento, nos casos em que é legalmente admitida, deverá conter ou fazer-se acompanhar por este aviso.

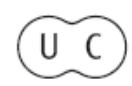


UNIVERSIDADE DE COIMBRA

FACULDADE DE LETRAS

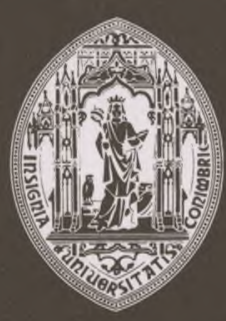

\section{CONIMBRIGA}

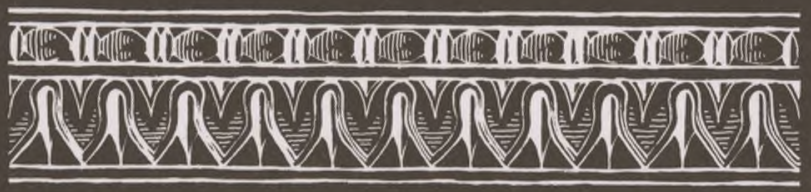

VOLUME XXXVII - 1998 
JORGE de AlARCÃo

Professor da Faculdade de Letras de Coimbra

\section{A PAISAGEM RURAL ROMANA E ALTO-MEDIEVAL EM PORTUGAL}

Conimbriga, XXXVII (1998), p. 89-119

Resumo: Distinguem-se três níveis de aglomerados populacionais no Portugal romano; cidades, vici e aglomerados de terceiro nível (<castella e aldeias). Se a aldeia parece não ter existido em algumas áreas (por exemplo, no Alentejo), é visível noutras regiões.

Quanto ao povoamento disperso, distinguem-se villae, granjas e casais, a que correspondem diferentes tipos de edifícios e diferentes propriedades. A villa teria, no Sul, cerca de 200 hectares (sem prejuízo de, a partir dos fins do séc. I d.C. e, sobretudo, no Baixo Império se terem constituído fundi mais vastos) e, no Norte, talvez 75 a 100 hectares. As granjas seriam propriedades de 10 a 50 hectares, também maiores no Sul do que no Norte. Os casais teriam propriedades de ordem dos $2 / 3$ a 10 hectares.

Apresenta-se uma proposta que permite identificar, a partir da área actual de dispersão dos achados superficiais, o tipo de edifício ou aglomerado subjacente. Analisam-se algumas áreas, procurando interpretar a paisagem em função destes parâmetros.

Conclui-se com uma análise do sentido da palavra villa nos documentos da Alta Idade Média.

Résumé: À l'époque romaine, il y avait, au Portugal, en plus des villes et des vici, des petits village s. Ils ne sont pas visibles dans toutes les régions. Dans le sud, le village n'existait pas: il n'y avait que des villes et des vici. Au contraire, dans le nord du pays, le village est visible.

Le peuplement rural dispersé se composait de villae, fermes et de modestes 
bâtiments avec des propriétés de $2 / 3$ à 10 hectares pour lesquels l'auteur propose, en portugais, le nom de casai. La villa était une propriété d'environ 200 hectares dans le sud et de 75 à 100 dans le nord. La ferme, pour laquelle l'auteur propose le noms portugais de granja, avait une propriété de 10 à 50 hectares.

À partir de l'extension des vestiges actuellement visibles en surface, on peut essayer d'identifier le type de site: petit village, villa, ferme ou casai. La carte archéologique de trois régions (Aquae Flaviae, Collippo et Egitânia) est interprétée en fonction de ces paramètres, en essayant de distinguer villes, fermes, petits villages et, pour le voisinage d'Egitania, des casais.

Finallement, l'auteur se pose les problèmes de la survivance des villas au Moyen Âge et du sens equivoque du mot villa dans les documents du $\mathrm{X}^{\mathrm{e}}-\mathrm{XII}{ }^{\mathrm{e}}$ siècles. 


\section{A PAISAGEM RURAL ROMANA E ALTO-MEDIEVAL EM PORTUGAL}

\section{A paisagem rural acontecida e agora imaginada e nomeada}

Alberto Sampaio imaginou o nosso territorio (inclusive o Entre Douro e Minho), na época romana, povoado de villae contíguas. "O solo das cividades, exceptuando porventura os tratos mais alpinos, saindo de vez do colectivismo, dividiu-se em secções de propriedade individual. Esta divisão, criando prédios de grande extensão, criou os núcleos fundamentais do mundo agrícola; em cada qual alojou-se um grupo de trabalhadores, às ordens e sob a direcção do dominus... Uma capital - urbs ou civitas, domina a região coberta de vilas... Estendendo-se contíguas, como as densas malhas de uma rede, as vilas foram um dos principais pontos de apoio da romanização..." (SAMPAIO, 1979: 111-112). Nas villae romanas teriam origem, segundo o autor, as villas da Reconquista.

Tivemos ocasião de contestar, em 1980, esta visão da paisagem rural romana de Portugal e de propor outra origem para as villas da Reconquista (ALARCÃO, 1980). É tempo de voltarmos a este assunto, agora mais documentados com resultados de trabalhos recentes de prospecções arqueológicas sistemáticas em diferentes áreas do país. Tempo de corrigirmos o critério demasiadamente estreito que naquele nosso artigo definimos para identificação das villae: o critério dos mosaicos.

$\mathrm{Na}$ época romana, como hoje, havia aldeias, de que a nossa figura 1 pretende dar uma imagem. Não as haveria no Alentejo, onde, para além das cidades, talvez só existissem vici, isto é, aglomerados urbanos de segundo nível, maiores que aldeias, que são aglomerados de terceira

Conimbriga, 37 (1998), 89-119 
ordem. Também na área de Viseu não são visíveis aldeias na época romana, a menos que chamemos aldeias aos antigos castros que se mantiveram sob o domínio romano (ALARCÃO, 1996). Mas na parte oriental de Trás-os-Montes, na zona de Chaves ou na área de Collippo (S. Sebastião do Freixo, Batalha) parece-nos ter existido algo a que convém o nome de aldeia. Possivelmente, a aldeia existiu noutras regiões do país.

Para além das aldeias, que devemos imaginar com um aro cultivado talvez da ordem de 1 a 1,5 quilómetro de raio (se não menor), havia, na época romana, um povoamento disperso de pequenas propriedades com habitações muito modestas, propriedades médias com habitações mais amplas e mais solidamente construídas e grandes herdades com sedes dotadas daquilo que Varrão chama urbana ornamenta: pavimentos de mosaico, revestimentos de estuque pintado nas paredes, termas, etc.

Para estas últimas casas e propriedades não temos dificuldade em encontrar uma designação: villa. Os muitos exemplos escavados permitem-nos imaginar o aspecto da casa do proprietário (fig. 2). Apar com esta, isto é, com aquilo a que Catão chama villa urbana e a que Columela dá o nome de pars urbana da villa, a grande herdade tinha sua pars rustica, que alojava os criados de lavoura e sua pars frumentaria, que reunia adega, celeiro, estábulos, eira, abrigos vários para a lenha e a palha, etc. A villa seria, em Portugal, uma propriedade de cerca de 200 hectares, sem prejuízo de, no Alentejo, poder alcançar 400 ou 600 e de, no Norte e Centro, poder descer a 75 ou 100.

As médias propriedades tinham habitações mais modestas, de que podemos fazer ideia através da fig. 3. Uma casa deste tipo cabia a uma média propriedade de 10 a 50 hectares. No Norte, uma média propriedade teria talvez 10 a 25 hectares; a sul do Tejo ou na zona da Idanha, onde a terra, na época romana, valia e rendia certamente menos, uma média propriedade poderia ter 50 hectares.

Que nome daremos a uma casa deste tipo e à propriedade média que the correspondia? Sentimo-nos, por um momento, tentados a chamar-lhe villa rustica, reservando o nome de villa, sem mais, para a grande propriedade e para a casa senhorial com os urbana ornamenta de Varrão. Mas a expressão villa rustica não ocorre na literatura latina com este sentido. O que Catão designa por villa rustica corresponde ao que Columela chama pars rustica da villa.

Conimbriga, 37 (1998), 89-119 
Talvez, pelo menos no tempo de Varrão, se chamasse também villa a este tipo de prédio, mas com a sensação de que a palavra era imprópria. Áxio (VARRÃO, Rer. rust. Ill, 2, 9) pergunta: Quid igitur, inquit, est ista villa, si nec urbana habet ornamenta neque rustica membra, que villa é esta que não tem nem os ornamentos urbanos nem as dependências rústicas?

Daqui parece dever deduzir-se que os prédios médios que consideramos se chamavam também villae, mas que já os Romanos sentiam a impropriedade do termo. Ora os arqueólogos franceses preferem designá-los pelo termo hoje corrente d e ferme', os ingleses, pelos de farm e farmstead. Porque é que não utilizaremos também um termo moderno?

Os autores do estudo sobre o ager Veientanus consideraram útil fazer uma distinção entre villa e farm, embora tenham reconhecido que essa distinção não se encontra na literatura clássica. E acrescentaram: "se bem que seja arbitrária a distinção entre villa efarm, ela expressa adequadamente as diferenças de riqueza e sofisticação da vida romana no âmbito do território (veientino)" (KAHANE, THREIPLAND e WARD-PERKINS, 1968: 153-154).

Os três termos possiveis para a média propriedade e para a casa correspondente são os de quinta, granja e casal. Mas o de quinta, embora o tenhamos já usado (ALARCÃO, 1997), não nos parece agora o mais conveniente. Nos séculos XIV e XV, as quintas eram "grandes casas de habitação, por vezes com várias divisões e sobradadas, celeiros, adegas, lagares, fornos, cavalariças, eventualmente mesmo uma torre" (GONÇALVES, 1989: 179). Hoje, "o tipo completo e perfeito da quinta é um prédio murado... a quinta tem uma casa de habitação, que muitas vezes é uma construção opulenta, rodeada por um jardim” (RIBEIRO, LAUTENSACH e DAVEAU, 1989: 866).

$O$ termo de granja era usado nos séculos XIV e XV para designar os prédios rústicos que os grandes proprietários (designadamente os senhorios monásticos) mantinham sob exploração directa; contrapunha-se a granja ao casal, que era o prédio arrendado ou aforado (GONÇALVES, 1989: 178; COELHO, 1989: 277 s; AMARAL, 1994: 50). Mas, nesta data, as granjas começaram também a ser arrendadas ou emprazadas. $O$ certo é que o termo caiu em desuso; exactamente por isso, isto é, por não ser conotado com nenhuma realidade moderna (hoje só existe na toponímia), talvez seja o mais adequado.

O termo casal correspondia, na Idade Média, a uma unidade de exploração não necessariamente contínua. Podia sê-lo e na documentação 
medieval encontram-se, a propósito dos casais, expressões como, “jaz em circuito cerrado sobre si" ou "está todo juntamente" (GONÇALVES, 1989: 171). Mas, nas mais das vezes, o casal era constituído por parcelas dispersas ou espalhadas: aqui uma leira de semeadura (ou várias leiras dispersas), além uma várzea, mais além uma vinha, noutro lugar um ferragial ou um pomar. A casa que encabeçava o casal podia estar reunida a outras, numa aldeia.

A dimensão de um casal, reunidas todas as parcelas, podia ultrapassar os 35 hectares, mas era geralmente muito menor (GONÇALVES, 1989: 176). Estudando a propriedade do mosteiro de Alcobaça, Iria Gonçalves concluiu que $52,8 \%$ dos casais se situavam entre os 3 e os 6 hectares. A documentação medieval não nos proíbe, pois, a utilização do termo casal para as propriedades médias romanas para as quais admitimos 50 hectares no Sul, talvez 10 a 25 no Centro e no Norte. Mas se utilizarmos a expressão casal para as médias propriedades, que nome daremos às pequenas, da ordem dos $2 / 3$ a 10 hectares? Poderíamos chamar grandes casais às primeiras e pequenos casais às segundas.

Não seria de todo despropositado usarmos para os pequenos casais a expressão latina de aedificia, que encontramos em César: Agros, aedificia, vicosque habebant (De bello Gallico, IV, 43). A fig. 4 dá-nos imagem do que César designaria por aedificium, residência da família que cultivava uma pequena propriedade.

Tudo ponderado, preferimos propor o termo de villa para a grande propriedade, o de granja para a média e o de casal para a pequena, de cuja casa a fig. 5 sugere uma imagem. Se a alguém repugnar a palavra granja, pode usar villa rústica. Note-se que não escrevemos villa rustica. Esta expressão, pelas razões já apontadas, é incorrecta para designar a média habitação e a correspondente propriedade. Pondo a palavra "rústica" em redondo, isto é, utilizando não o latim mas o romance, a expressão pode ser aceitável.

A distinção entre villa, granja e casal não deve fazer-nos esquecer que havia provavelmente algumas villae diminuídas ao ponto de serem quase granjas, granjas ricas no caminho de virem a ser villae e alguns casais graúdos quase granjas. 


\section{O metro que interpreta}

Como julgar, a partir dos vestígios superficiais que encontramos, e anteriormente a qualquer escavação, se estamos em presença de um casal, de uma granja ou de uma villal Ou ainda de uma aldeia?

Digamos, antes de mais, que a interpretação não pode deixar de ser mera conjectura; mas não será preferível correr o risco de conjecturar a designar todas as estações pelo nome genérico de habitat? Será que não temos meios de saber o que ali foi $\mathrm{e}$ devemos ficar desistidos de pensar o que ali houve?

Conjugando os dados de várias prospecções, parece-nos possível propor alguma correlação entre a área de dispersão actual dos achados e o tipo de estação.

Um sítio com 100 a $1.000 \quad \mathrm{~m} 2$ (referimo-nos sempre à área de dispersão actual dos achados) corresponderá a um casal; uma estação com 1.000 a $5.000 \mathrm{~m} 2$, a uma granja; um lugar com 5.000 a $25.000 \mathrm{~m} 2$, a uma villa $\$ finalmente, a partir de $10.000 / 15.000 \mathrm{~m} 2$, teremos aldeias.

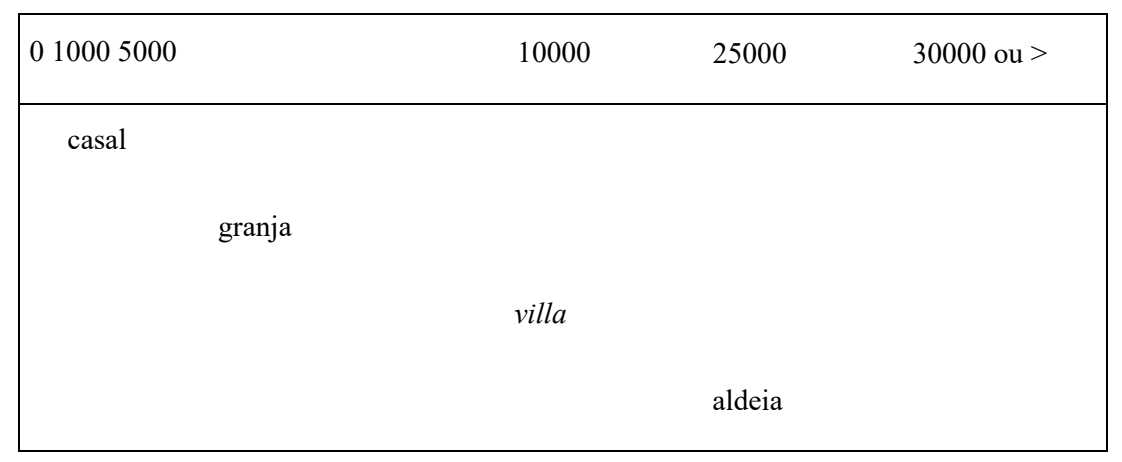

Voltemos aos casais. A sua dimensão média parece ser mais frequente entre os 400 e os $600 \mathrm{~m} 2$. Mas nem todos os sítios desta dimensão, ou, mais genericamente, entre 100 e $1.000 \mathrm{~m} 2$, serão casais. Numa zona de villae, temos de perguntar-nos se estações desta ordem de grandeza não correspondem antes a anexos ou a edifícios subsidiários de villae: a casa do guarda da vinha (a que Isidoro de Sevilha, XV, 12,

1-2 dá o nome de tugurium ou capanna), a cabana do lenhador na orla do bosque, a cabana do pastor, etc. As estações de 100 a $1.000 \mathrm{~m} 2$ que se 
situem, no Sul, numa área de 200 hectares em tomo de uma villa (ou, no Centro e no Norte, numa área de 75 a 100 hectares) devem ser classificadas como prováveis anexos de villae mais do que como casais, como sugere a nossa fig. 6, que aponta a cabana do lenhador no bosque, a do pastor no saltus, as dos guardas da vinha e do pomar, a do hortelão.

Os achados que encontraremos nos casais ou nos anexos de villae reduzir-se-ão a tegulae, imbrices e cerâmica comum.

Nas granjas já se pode esperar alguma sigillata ou sigillata clara, algum resto de opus signinum, algum tijolo de coluna, fuste tosco de pedra local ou capitel simples toscano.

Ainda que tenhamos definido os $5.000 \mathrm{~m} 2$ como limite inferior das villae, qualquer achado de tesselae de mosaico ou de escultura deve ser suficiente para classificarmos como villa uma estação menos extensa. Mas o inverso não é verdade: pode haver villae sem mosaicos.

Se a presença de termas é comum numa villa, não devemos identificar como tal toda e qualquer estação com termas: pode tratar-se de uma mansio, que obrigatoriamente se situará no percurso de uma via.

Quando é que uma estação entre os 10.000 e os 25.000 hectares se classificará como aldeia? Se tiver mosaicos, mármores de revestimento, sigillata ou sigillata clara, cerâmica de paredes finas, lucemas, vidros, será villa. Uma estação desta grandeza só com cerâmica de construção e cerâmica doméstica comum será uma aldeia, cuja área poderá ultrapassar os $30.000 \mathrm{~m} 2$. Mas talvez se deva chamar já vicus a uma estação cuja área de dispersão de achados ronde ou ultrapasse os $30.000 \mathrm{~m}^{2}$.

Permitirá o nosso metro dar um sentido aos vestígios ou será irresultante?

Analisaremos adiante alguns casos mas abordemos primeiro o problema da dimensão dos fundi.

\section{As áreas dos fundi}

Gorges (1979: 98-99), num trabalho sobre as villae romanas da Península Ibérica, calculou a extensão das villae do Alentejo entre 1.500 e 8.000 hectares; e noutro estudo (ETIENNE e GORGES, 1979: 903) sugeriu 3.000 a 4.000 hectares para as propriedades romanas da área de Castelo de Vide. É hoje evidente que estes números são excessivos.

No âmbito dos trabalhos arqueológicos que se realizaram em S. Cucufate, P. Sillières e V. Mantas calcularam em 200 hectares a dimensão 
média das villae da área da Vidigueira e de Cuba (in ALARCÃO, ETIENNE e MAYET, 1990: 180). Reutilizando os dados colhidos na zona de S. Cucufate, defendemos a possibilidade de as villae alentejanas poderem ter alcançado 400 hectares (ALARCÃO, 1990: 419).

É nestes parâmetros que devem situar-se as villae romanas do Alentejo, como claramente se deduz de um estudo recente efectuado por Maria da Conceição Lopes e Pedro Carvalho no concelho de Serpa. Mas voltemos ao caso de S. Cucufate e analisemos a carta da fig. 7.

O território da civitas de Pax Iulia foi centuriado e cada centúria correspondeu a 50 hectares (MANTAS, 1996). A malha quadrangular a traço fino da nossa carta representa centúrias dessa grandeza, com a orientação proposta por Vasco Mantas. De poente para nascente temos cinco villae: $\mathrm{n}^{\circ}$. 65 ( $\left.15.000 \mathrm{~m} 2\right), 9(5.000 \mathrm{~m} 2), 1$ (20.000 m2), 43 (10.000 $\mathrm{m} 2)$ e $48(5.000 \mathrm{~m} 2)$. A dimensão de 200 hectares para cada villa parece conveniente. É certo que, tendo sido limitada a área da prospecção, podemos defender a hipótese de o fundus de S. Cucufate $\left(\mathrm{n}^{\circ}\right.$. 1) se continuar para ocidente, o de Boa Vista $\left(\mathrm{n}^{\circ}\right.$. 9) se prolongar para norte. Para cada villa podemos defender, teoricamente, territórios maiores; mas estes não parecem muito prováveis.

Nas propriedades de 200 hectares comandadas por cada villa temos estações inferiores a $1.000 \mathrm{~m} 2$. Assim, e relativamente à villa de Pedras de Zorra ( $\mathrm{n}^{\circ}$. 65), temos os $\mathrm{n}^{\text {os }} .57$ (duas concentrações de $200 \mathrm{~m} 2$ a curta distância uma da outra), $62(500 \mathrm{~m} 2), 63(300 \mathrm{~m} 2), 64(50 \mathrm{~m} 2), 59(500$ $\mathrm{m} 2), 60(200 \mathrm{~m} 2), 61(500 \mathrm{~m} 2), 58(100 \mathrm{~m} 2)$ e $13(1.000 \mathrm{~m} 2)$. De acordo com a nossa proposta, teríamos aqui dependências da villa.

Os triângulos da nossa carta marcam as estações que, por terem entre 1.000 e $5.000 \mathrm{~m} 2$, classificamos de granjas. Não deixa de ser aceitável atribuirmos 50 hectares a cada uma destas propriedades. A classificação dos nos. 14 e 16 pode suscitar reservas; mas observaremos que estão nos limites da villa de S. Cucufate $\left(\mathrm{n}^{\circ}\right.$. 1). Seriam as propriedades tão rigorosamente esquadriadas?

Observe-se que algumas granjas têm também estabelecimentos dependentes e que não há, nesta área, nada que nos obrigue a defender a ideia de unidades menores, isto é, de casais da ordem dos $2 / 3$ a 10 hectares. Os $\mathrm{n}^{\text {os }}$. 38 e 39, que poderíamos admitir repartirem uma centúria de 50 hectares, têm, respectivamente, 200 e $150 \mathrm{~m} 2$, isto é, dimensões muito inferiores à média de 400 a $600 \mathrm{~m} 2$ que presumimos para os casais: parece melhor classificá-los como estabelecimentos anexos (da granja $\left.n^{\circ} .16 ?\right)$. 
O estudo de Maria da Conceição Lopes e Pedro Carvalho no concelho de Serpa confirma a impressão de que a dimensão média das villae do Alentejo era de 200 hectares embora pudesse, nalguns casos, atingir os 400. Não exluímos, todavia, a possibilidade de um rico proprietário poder reunir diversas villae ou ter na sua dependência algumas granjas.

Propriedades desta grandeza, isto é, da ordem dos 200 hectares, poderiam existir no Centro e até no Norte do país. Examinemos alguns casos do território de Conimbriga.

A villa de S. Simão, no concelho de Penela, conhecida por mosaicos, fica situada num vale chamado da Cerradinha, apertado entre o Outeiro da Presa e a Lomba da Avessada. Espraia-se depois o vale pelo campo do Pastor. À vontade, a villa podia dispor de 200 hectares de boas terras (fig. 8).

No sítio do Carvalhal, no concelho de Ansião, há umas longas galerias subterrâneas que parecem constituir criptoportico de uma $\mathrm{O}$ sítio domina uma várzea fértil cercada de montes: o Monte Alvão e o Morro da Ladeira. A várzea tem mais de 450 hectares, mas parece ter sido repartida pela villa do Carvalhal e por uma outra sita em Santiago da Guarda, onde há mosaicos (fig. 9).

\section{Castella, aldeias e villae na área de Chaves}

A carta arqueológica da região de Chaves, na época romana (fig.

10) foi elaborada por Paulo Amaral numa meritória tese de mestrado apresentada em 1993 à Faculdade de Letras do Porto. O autor teve o cuidado de medir a área de dispersão actual dos vestígios mas classifica como habitat muitas estações, sem se interrogar se se trata de granjas, villae ou aldeias.

Ao longo do Tâmega e da via romana que, de Chaves, se dirigia para o Norte, a montante da cidade, temos uma série de estações com

7.000 a $20.000 \mathrm{~m} 2$, que nos parecem, pela extensão, de norte para sul, 72, 74, 76, 79, 71. Pela sua posição, a estação 78, cuja área de dispersão o autor não conseguiu calcular, poderá corresponder a outra villa. Mais incerta é a classificação da estação 144, a norte, com 15.000 $\mathrm{m}^{2}$, "alguns silhares bem faceados... um fuste de coluna cilíndrico, um capitel de tipo toscano-provincial..." Considerada a distância a que este sítio se encontra de Aquae Flaviae (10 quilómetros), poderá tratar-se de 


\section{uma mutatio.}

A juzante da cidade, as estações 132, 94, 92, 114, ainda no Vale do Tâmega e 10, esta junto da ribeira de Vidago, corresponderão igualmente a villae.

Um outro grupo de villae regista-se a sul da cidade, ao longo de uma via secundária cujo traçado hipotético Paulo Amaral define: 111, $65,66,98(?), 58$ e $59(?)$.

Os círculos que traçamos em redor destas villae representam propriedades da ordem dos 75 hectares. É evidente que propriedades desta ordem de grandeza e até maiores seriam possíveis.

Os povoados fortificados de Paulo Amaral, isto é, os antigos castros romanizados dispersam-se por todo o território.

Sobretudo na zona a noroeste e a norte da cidade surgem diversas estações de 15.000 a $50.000 \mathrm{~m}^{2}$, isto é, extensas, mas sem outros materiais para além de tegulae e imbrices e cerâmica doméstica comum. De acordo com a nossa proposta, classificá-las-emos como aldeias. São elas os números 123, 48, 50, 18, 21, 146, 141 e 143.

A estação 18, onde, além de cerâmica de construção e de cerâmica doméstica comum, se encontraram silhares bem faceados e um fuste de coluna, poderá corresponder a uma aldeia onde existiria uma mutatio, edifício ao qual se poderiam atribuir os silhares e a coluna.

$\mathrm{Na}$ estação 143, para além de um fragmento de sigillata hispânica, foram encontrados silhares bem faceados. Com $30.000 \mathrm{~m}^{2}$, a estação ultrapassa o limite máximo de $25.000 \mathrm{~m}^{2}$ que propomos para as villae. Se se tratasse de uma grande villa, deveríamos encontrar mais materiais nobres. Com um mísero fragmento de sigillata, esta estação corresponde mais provavelmente a uma aldeia com um proprietário mais rico, a cuja casa atribuiremos hipoteticamente a sigillata $\mathrm{e}$ as pedras faceadas. O mesmo diremos da estação 146, com $50.000 \mathrm{~m}^{2}$, com alguma sigillata hispânica e duas bases de colunas.

As aldeias, assim concentradas a norte e noroeste da cidade, são mais raras no resto do território. Ainda assim, classificaremos como tais as seguintes estações na margem esquerda do Tâmega: 55, 43 e 115. A volta das aldeias e dos castros romanizados traçámos círculos de cerca de 150 hectares.

Serão detectáveis granjas no território de Chaves? Apontamos como hipótese os sítios 49, 88, 151, 150, 69, 110 e 99, todos com 5.000 $\mathrm{m}^{2}$ mas sem materiais nobres.

Não há, na área, estações que possam classificar-se como casais

Conimbriga, 37 (1998), 89-119 
ou anexos de villae. Terão escapado à prospecção de Paulo Amaral?

Parece-nos conveniente anotar ainda a posição de algumas villae $(20,102)$ e de uma granja (8). Ficam situadas no aro do que seriam povoados fortificados. A situação de uma villa ou granja no território de um castro é curiosa mas não é inédita.

Esta paisagem de castella, aldeias e villae mantinha-se em 872, porque, nessa data, um illustrissimo viro domno Odoario digno bellatori... venit in civitate Flavias secus fluvium Tamice... e vicos et castella erexit e civitates munivit et villas populavit atque eas certis limitibus firmavit et terminis certis locavit et inter utrosque abitantes divisit (LOPEZ ALCINA, 1988: 202, nota 290).

Que dimensão teriam as presumíveis aldeias romanas da área de Chaves? No Barroso, actualmente, as aldeias têm uma área de exploração de $1350 \mathrm{~m}$. de raio (LEMA, 1978: 80). Semelhante área é perfeitamente admissível para algumas aldeias romanas da região flaviense. Mas, no caso de 18, 47, 48 e 50 e, sobretudo, no de 19, 21 e 24, os territórios, mesmo reduzidos a $700 \mathrm{~m}$. de raio (isto é, c. de 150 hectares, que foi,

\section{Estações da área de Chaves}

\begin{tabular}{|c|c|c|c|l|}
\hline $\mathrm{N}^{\circ}$. & Cias. de P. Amaral & Área em m2 & Nossa classificação & \multicolumn{1}{|c|}{ Achados } \\
\hline 8 & Habitat & 15 & Aldeia & \\
9 & “ & 10 & “ & c.; m. \\
10 & Villa? & 15 & Villa & t.s.; c.; s. \\
18 & Habitat & 25 & Aldeia (mutatio?) & s. \\
20 & “ & 5 & Villa! & t.s.; c. \\
21 & Villa? & 20 & Aldeia? & t.s.; s.; c. \\
29 & Habitat & 7 & Villa! & s.; e. \\
34 & “ & 15 & “ & t.s.; s. \\
43 & Villa! & 45 & Aldeia & t.s.; c. \\
48 & Habitat & 30 & “ & t.s.; s.; m. \\
49 & “ & 5 & Granja & \\
50 & “ & 15 & Aldeia & \\
55 & “ & 75 & “ & \\
\hline
\end{tabular}

Conimbriga, 37 (1998), 89-119 


\begin{tabular}{|c|c|c|c|c|}
\hline 58 & “ & 15 & Villa & t.s. \\
\hline 59 & “ & 5 & Granja & \\
\hline 65 & “ & 5 & Villa? & ep. \\
\hline 66 & “" & 10 & Villa & t.s. \\
\hline 69 & "“ & 5 & Granja & \\
\hline 71 & Villa? & 20 & Villa & t.s.; c.; s. \\
\hline 72 & Habitat & 20 & “ & t.s.; m. \\
\hline 74 & “ & 10 & “" & t.s. \\
\hline 76 & “ & 15 & “ & c. \\
\hline 78 & Villa! & $?$ & Villa? & ep.; s.; c. \\
\hline 79 & Habitat & 7 & Villa & t.s.; s. \\
\hline 88 & “ & 5 & Granja & $\mathrm{m}$. \\
\hline 92 & Villa? & 10 & Villa & mos. (?); s. \\
\hline 93 & Habitat & $?$ & $?$ & \\
\hline 94 & Villa? & 15 & Villa & t.s.; s.; c. \\
\hline 98 & Habitat & 10 & Aldeia & \\
\hline 99 & “ & 5 & Granja & c. \\
\hline 100 & “ & 10 & Aldeia & \\
\hline 102 & Villa? & 5 & Villa & t.s.; s. \\
\hline 107 & Habitat & 10 & Villa? & t.s.; s. \\
\hline 110 & “ & 5 & Granja & s. \\
\hline 111 & Villa? & 15 & Villa & t.s.; s.; c.; m. \\
\hline 114 & Habitat & 10 & “ & ep.; s.; m. \\
\hline 115 & “ & 15 & Aldeia? & \\
\hline 121 & Villa? & 15 & Mutatio? & t.s.; c. \\
\hline 123 & Habitat & 40 & Aldeia & \\
\hline 132 & Villa & 5 & Villa & mos.;o.s.;c.; \\
\hline & & & & s.; e.;ep. \\
\hline 141 & Habitat & 30 & Aldeia & s. \\
\hline 143 & “ & 30 & “ & t.s.; s. \\
\hline 144 & "“ & 15 & Aldeia (mutatio?) & c. \\
\hline 146 & Villa? & 50 & Aldeia & t.s.; c. \\
\hline 150 & “ & 5 & Granja & \\
\hline 151 & Habitat & 3.5 & Granja? & \\
\hline 152 & “ & 15 & $?$ & s. \\
\hline
\end{tabular}

CHAVE: c. colunas e/ou capitéis e. escultura ep. epígrafes m. moedas mos. mosaicos - o. s. opus signimum s. silhares t.s. terra sigillata

Conimbriga, 37 (1998), 89-119 
como dissemos, a dimensão que demos aos territórios das nossas aldeias flavienses) sobrepõem-se. Talvez possamos considerar as estações 48 e 50, separadas por apenas 500 metros, como dois núcleos de uma mesma aldeia ou descentrar os territórios. No outro caso, talvez a aldeia 141, aparentemente tardo-romana, tenha substituído a aldeia 146, que parece dever atribuir-se ao séc. I ou II. O castro 147 talvez não tenha sido romanizado.

Uma aldeia com um território de apenas 150 hectares tinha necessariamente de ser uma povoação pequena. No Barroso, apenas 30\% do território das aldeias corresponde a terrenos cultivados; $70 \%$ consiste em pastos e matas. Se aplicarmos as mesmas percentagens às aldeias romanas, o território de 150 hectares teria só 45 de terras cultivadas. Se atribuirmos 5 hectares a cada fogo, a aldeia teria 9 fogos, isto é, 45 habitantes; se lhe atribuirmos 2,5 hectares, teria 18 fogos, isto é, 50 habitantes. E entre estes parâmetros - 9 a 18 fogos - que devemos imaginar a aldeia romana da região flaviense.

\section{A área de Idanha-a-Nova}

A prospecção arqueológica em tomo de Egitânia foi feita por Pedro Carvalho, Luís Fernandes e José Ruivo, que apresentaram, no $3^{\circ}$. Congresso Peninsular de História Antiga (1994), uma comunicação da qual, por enquanto, só existe síntese de pré-publicação. A prospecção foi realizada no âmbito do nosso seminário de Arqueologia e completada por Vitor Pedrosa, num outro trabalho de seminário (1996), inédito.

A nossa fig. 11 apresenta as estações localizadas pelos autores mencionados. De acordo com os parâmetros atrás apresentados, identificámos casais, granjas e uma villa; e dotámos os primeiros de propriedades da ordem dos 5 hectares; as granjas, de propriedades de 50 hectares; a villa, de um fundus de c. 100 hectares.

O panorama obtido é, pelo menos, credível. Perto da cidade observam-se cinco granjas e uma série de casais. Quatro destes (n ${ }^{\text {os }}$. 17, 70, 66 e 59) caem dentro do hipotético fundus da granja $n^{\circ}$. 16: teria esta uma propriedade menor que 50 hectares, ou aqueles números correspondem, não a casais, mas a simples anexos da granja? $\mathrm{O}$ edifício correspondente ao sítio $\mathrm{n}^{\circ}$. 16, onde D. Fernando de Almeida fez uma sondagem, tinha "um tanque circular em um possível pátio" (ALMEIDA, 1977: 16). O autor classifica este sítio como villa. É também possível 
que se trate efectivamente de uma villa que, por muito próxima da cidade, teria um pequeno fundus.

Os sítios 53, 66 e 70 também poderão corresponder a necrópoles da cidade. Os sítios 19 e 20 são, na interpretação de Pedro Carvalho, Luís Fernandes e José Ruivo, necrópoles da Egitânia.

A estação $\mathrm{n}^{\circ}$. 69, a poente do $\mathrm{n}^{\circ}$. 23, tem $3.000 \mathrm{~m} 2$. De acordo com os nossos parâmetros, deveríamos fazer dela a sede de uma nova granja. A verdade é que, sendo vasta a área de dispersão dos achados, estes se reduzem a materiais cerâmicos de construção: não teremos aqui uma telharia, isto é, uma oficina para o fabrico de telhas e tijolos?

As estações $n^{o s} .44$ e 45 seriam anexos da granja $n^{\circ} .45 \mathrm{~A}$, com

$2.000 \mathrm{~m} 2$. No âmbito do fundus desta granja insere-se um forno cerâmico escavado por Fernando de Almeida.

A villa $\mathrm{n}^{\circ}$. 29, com $7.000 \mathrm{~m} 2$, incorpora, no seu hipotético fundus de 100 hectares, várias pequenas estações em torno das quais traçámos círculos como se se tratasse de casais; mas não estaremos antes em presença de estabelecimentos anexos da villal

A hipótese de uma villa no sítio $\mathrm{n}^{\circ}$. 29 entra, de algum modo, em conflito com a identificação da estação $\mathrm{n}^{\circ}$. 33 (com mais de $1.000 \mathrm{~m}^{2}$ ) como granja. Os respectivos fundi sobrepõem-se parcialmente. Várias hipóteses são possíveis. Em primeiro lugar, o sítio $\mathrm{n}^{\circ}$. 29 seria efectivamente uma villa mas, dada a sua proximidade da cidade, teria um fundus de apenas 50 hectares, que representamos a tracejado na fig. 11. Numa segunda hipótese, o sítio $\mathrm{n}^{\circ} .33$ não seria uma granja, mas apenas um casal abastado, com um fundus menor que 50 hectares. Em terceira hipótese, os $\mathrm{n}^{\text {os }}$. 29 e 33 não ficariam no centro dos respectivos fundi.

A incerteza quanto à interpretação destas duas estações reflecte-se na interpretação dos nos. 32, 62, 35 e 37: seriam anexos da villa e da granja ou casais autónomos?

O sítio $\mathrm{n}^{\circ}$. 71, com $6.000 \mathrm{~m} 2$, deveria também classificar-se como villal mas, porque não apresenta, à superfície, senão cerâmica de construção e nenhuma cerâmica fina, preferimos classificá-lo hipoteticamente como granja. Por outro lado, fica demasiadamente próximo da cidade para poder ser classificado como aldeia.

No âmbito da granja 49A fica situada uma barragem (QUINTELA, CARDOSO E MASCARENHAS, 1995: 92). Serviria para irrigar os terrenos das granjas nos. 49A e 45A?

Em conclusão: parece-nos viável interpretar a paisagem em tomo 
da Egitânia como uma série de casais que poderiam ter 5 hectares (ou um pouco mais) e de granjas de 50 hectares, com uma villa duvidosa de 100 hectares; não é visível, neste território, nenhuma villa de 200 hectares, o que não significa que propriedades desta dimensão não tenham existido noutras áreas da civitas egitaniense. Algumas áreas há tão sem nada de cacos que, olhando o vazio, nos lembramos poderem ter sido outrora pinhais ou azinhais, acudindo à necessidade que a cidade tinha de lenha. Infelizmente, não podemos traçar as vias que vinham desaguar à Egitânia e por onde avançavam, pesadolentos, os carros de bois carregados. A área a nascente, entre os $n^{\text {os }}$. 23 e 26, por um lado, e os $n^{\text {os }} .65,27$ e 64, por outro, não foi devidamente prospectada e talvez venham a encontrar-se aqui outras estações.

\section{O território de Collipo}

No território de Collippo (fig. 12), João Pedro Bemardes (1996) identificou 15 villae, entre certas e prováveis. Parece-nos que pode elevar-se o número para 19 (nem todas seguras) ou talvez mesmo para 20. Afigura-se-nos incerta a classificação dos sítios $\mathrm{n}^{\text {os }}$. 55 (com 25.000 m2) e 57 (com $20.000 \mathrm{~m} 2$ ). Cabem, pela área de dispersão dos achados, tanto na categoria de villae como na de aldeias. A ausência de outros vestígios para além de cerâmica de construção e de pedras toscamente aparelhadas faz-nos duvidar da classificação do sítio $\mathrm{n}^{\circ} .55$ como villa mas não estará demasiadamente próximo da capital para ser aldeia? Quanto à estação $\mathrm{n}^{\circ}$. 57, que João Pedro Bemardes classifica como villa (?), não podemos excluir essa hipótese, embora não se tenha aí achado terra sigillata nem qualquer tipo de cerâmica fina romana; mas há fragmentos de colunas e foi aí encontrado um tesouro de cerca de 1.000 denários que parece ter incluído moedas de Augusto e Tibério (RUIVO, 1995: 16-17).

Talvez não haja, no território de Collippo, muitas mais villae a descobrir. Civitates como as de Aeminium, Conimbriga, Collippo, Eburobrittium ou Sellium não teriam mais de uma vintena de grandes proprietários. No território de Conimbriga, por exemplo, temos localizadas, até agora, 12 villae. No territorio de Sellium, há 13 sitios que podem classificar-se como villae. A prospecção nestes territorios poderá descobrir algumas mais.

Dadas as distâncias a que as villae de Collippo se encontram umas 
Estações da área de Collipo

\begin{tabular}{|c|c|c|c|c|}
\hline $\mathrm{N}^{\circ}$. & J.P. Bernardes & Área & Nossa proposta & Achados \\
\hline 6 & Casal & 5 & Granja & \\
\hline 10 & Vicus & 30 & Vicus & s.; c. \\
\hline 14 & Casal & 4 & Granja & \\
\hline 15 & Vicus & 7.5 & Aldeia & \\
\hline 17 & Villa & 12 & Villa & t.s.; s. \\
\hline 18 & Vicus & 30 & Vicus & t.s. \\
\hline 19 & Quinta & 6 & Villa & \\
\hline 21 & Villa & 5 & $a$ & mos.; m.; c. \\
\hline 26 & “ & 8 & “" & mos.; m. \\
\hline 27 & Quinta & 7 & " & $\mathrm{s} . ; \mathrm{m}$. \\
\hline 29 & Villa & 20 & “" & c. \\
\hline 30 & Quinta & 10 & "“ & \\
\hline 37 & “ & 5 & Granja & s.; c. \\
\hline 40 & Villa & 15 & Villa & mos.; m.; s. \\
\hline 45 & “ & $?$ & “ & \\
\hline 51 & “" & 20 & “ & ep.; s.; e. \\
\hline 54 & Casal & 5 & Granja & \\
\hline 55 & Quinta & 25 & Villa & c. \\
\hline 57 & Villa & 20 & “ & m.; c. \\
\hline 58 & “ & 25 & “ & m.; s.; t.s. \\
\hline 59 & Casal & 4 & Granja & \\
\hline 60 & Habitat & 4 & “ & \\
\hline 62 & Villa & 8 & Villa & ep.; c. \\
\hline 63 & Casal & 4 & Granja & \\
\hline 69 & Quinta & 8 & Villa & c.; m. \\
\hline 70 & Villa & 20 & “ & \\
\hline 71 & “ & 15 & "“ & mos.; op. s.; \\
\hline 74 & “ & $?$ & “ & \\
\hline 76 & “" & 15 & & e.; ep.; m. \\
\hline 77 & Vicus & 30 & Vicus & ep. \\
\hline 83 & Quinta & 5 & Granja & $\mathrm{m}$. \\
\hline 85 & Villa & $?$ & Villa & ep. \\
\hline 86 & Habitat & 10 & Aldeia & \\
\hline 88 & “ & 18 & & \\
\hline 89 & Vicus & 30 & Vicus & $\mathrm{m}$. \\
\hline 93 & “ & 40 & “ & c. \\
\hline 97 & Habitat & 20 & Aldeia & \\
\hline
\end{tabular}

Conimbriga, 37 (1998), 89-119 
das outras, são perfeitamente admissíveis propriedades da ordem dos 200 hectares; seriam até possíveis propriedades muito maiores.

A relativa riqueza da epigrafia romana da civitas de Collippo permite identificar algumas famílias proprietárias de certas villae. A família Aufídia tinha as villae $\mathrm{n}^{\mathrm{os}}$. 62 e 71 ; ou, talvez, mais correctamente, mulheres desta família casaram com proprietários destas villae: um Quinto Ligúrio Rústico, casado com uma Aufídia, terá sido, em algum tempo no séc. I d.C., proprietário da villa $\mathrm{n}^{\circ}$. 62; e um Flávio Avito, igualmente casado com uma Aufídia, terá sido proprietário da villa $\mathrm{n}^{\circ}$. 71. A família Valéria, talvez ligada por laços matrimoniais à anterior familia de Flávio Avito, foi proprietária da villa $\mathrm{n}^{\circ}$. 45. Mulheres da rica família Labéria casaram com proprietários das villae ${ }^{\text {os }}$. 51 e 85 . A família Carísia foi proprietária da villa $\mathrm{n}^{\circ} .76$.

De acordo com os nossos critérios, são raras as propriedades classificáveis como granjas e não há nenhuma identificável como casal. Esta raridade e esta ausência derivam, possivelmente, de falta de prospecção sistemática.

Caminhando de sul para norte, vemos aldeias nas estações 89 e 77. Ambas com $30.000 \mathrm{~m} 2$, poderiam ser mesmo vici. É como vici que João Pedro Bemardes as classifica, embora dubitativamente. Dada a posição em que se encontram e a distância a que 89 se acha de 77 , e esta, da capital da civitas, podem ter funcionado como mutationes.

Localizamos outras aldeias em 86, 88 e 93. Parecem-nos demasiadamente próximas umas das outras. Mas João Pedro Bemardes não encontrou materiais indiscutivelmente romanos no sítio $\mathrm{n}^{\circ}$. 88 , admitindo que a cerâmica de constmção aí achada possa ser medieval. Quanto á estação $\mathrm{n}^{\circ}$. 93, com $40.000 \mathrm{~m} 2$, o autor sugeriu, possivelmente com razão, tratar-se de um vicus.

A margem da via que saía de Collippo para norte, encontramos outras três aldeias, duas das quais, os sítios nos. 10 e 18 , com $30.000 \mathrm{~m}^{2}$, podem corresponder a vici. E como tais, aliás, que João Pedro Bemardes os classifica. Atribui também a mesma categoria à estação $\mathrm{n}^{\circ}$. 15, que, vista a sua modesta área $(7.500 \mathrm{~m} 2)$, inferior ao limite que hipoteticamente definimos para a aldeia, nos parece corresponder antes a um povoado muito modesto. 


\section{Sobre a cronologia das villae}

O problema da cronologia da instalação das primeiras villae é dificil de abordar por falta de dados arqueológicos.

No Baixo Alentejo parece ter-se verificado, já nos meados do séc. I a.C., o estabelecimento de colonos itálicos, como esse Lúcio Comélio Mitulo cuja inscrição funerária se encontrou em Casével (Castro Verde) (DIAS, 1986). Esses primeiros colonos terão edificado aquelas residências identificadas por Manuel Maia e a que impropriamente se dá o nome de castella. O Castelo da Lousa (WAHL, 1985) é o exemplo mais conhecido, cuja fundação talvez se possa atribuir ainda à época de César. Mas deveremos chamar villae a estas propriedades? Não será mais apropriado o nome de granjas?

A presença de cerâmica campaniense em várias das villae do território olissiponense (SOUSA, 1996) deixa supor estabelecimentos rurais de certa importância já na primeira metade do séc. I a.C.; mas não temos plantas dessas villae republicanas.

Ainda na época republicana ou na de Augusto, colonos mais aventureiros parece terem-se estabelecido em áreas mais a norte, eventualmente junto a castros. Um exemplo é talvez esse Lúcio Mânlio, da tribo Emilia, que dedicou aos (diis) Peinticis uma inscrição rupestre junto ao castro de Três Rios (Tondela) (UNTERMANN, 1965). Que faria este Lúcio Mânlio na Beira ainda em época republicana? Não seria um colono instalado em sua villa?

$O$ tesouro de denários da Moita (Anadia) (HIPÓLITO, 1960-61: 50-51), datável de 67 a.C., que não parece equacionável com nenhum castro, mas que se encontrou numa panela de ferro no interior das ruínas de uma casa com canalização de tijolo (segundo as parcas informações de que dispomos), não indiciará outro colono aventureiro?

Outro caso, agora augustano, é o de Décimo Júlio Cilo, estabelecido junto ao castro da Senhora da Saúde (Vila Nova de Gaia) (SILVA, 1983).

Infelizmente, porém, não temos ideia do tipo de residência destes colonos: viveriam em edificios já qualificáveis de villael Aqueles que viviam junto a castros teriam pars rustica e criados de lavoura residentes? Ou seria o trabalho dos campos assegurado pelos castrejos que vinham e regressavam todos os dias ao castro?

No território de Pax Iulia, a centuriação em lotes de 50 hectares datará da época de Augusto. É possível que logo tenham surgido 
propriedades de 200 hectares, isto é, reunindo quatro lotes. Por este lado, seriam villae. Mas as habitações poderiam ser modestas. Não temos, por enquanto, nenhuma escavação de edifício da época de Augusto. A primeira villa de S. Cucufate parece datar de meados do séc. I d.C. e essa é a data também atribuível à villa da Boa Vista (ALARCAO, ETIENNE, e MAYET, 1990). Nesta, temos um nítido peristilo; mais modesta, a villa I de $\mathrm{S}$. Cucufate integra também algo que pode classifícar-se de peristilo.

O fenómeno da emergência das villae parece mais tardio no Norte. Das onze villae com sigillata da área de Chaves (AMARAL, 1993), só duas apresentam sigillata sudgálica; nas restantes nove recolheram-se apenas fragmentos de sigillata não anteriores ao último terço do séc. I d.C. Sem esquecer o carácter aleatório de datações baseadas apenas em recolhas superficiais e amostragens muito reduzidas, podemos propor a época flaviana para a emergência das villae no Alto Tâmega. Para o território de Collippo não temos quaisquer dados arqueológicos que nos permitam datar a fundação das villae, se bem que uma data cláudio-neroniana se nos afigure possível. Mas não será anterior a imigração, para esta área, das grandes famílias de colonos como a dos AlfidiP

No concelho de Serpa, a maioria das villae localizadas por Maria da Conceição Lopes e Pedro Carvalho (LOPES, CARVALHO e GOMES, no prelo) parece ter sido fundada nos inícios do séc. I d.C. e ter perdurado pelo menos até ao séc. IV ou V, pois os materiais recolhidos na maior parte dos sítios vão da sigillata itálica à sigillata clara D. Não terá havido, na área de Serpa, concentração de propriedade no Baixo Império mas ter-se-ão mantido os fundi, isto é, não são aparentes villae abandonadas que possam ter sido adquiridas por proprietários de outras villae. O abandono das villae ter-se-á verificado no período das invasões bárbaras, com algumas excepções, a mais notável das quais é, na área de Serpa, a da Cidade das Rosas, com ocupação muçulmana, todavia insúflente para podermos assegurar que ainda ali residia, nessa época, um proprietário influente.

A permanência das villae do Sul de Portugal no período islâmico parece um fenómeno mais pontual que generalizado. É evidente na Cidade das Rosas (Serpa), na Herdade da Cegonha (Vidigueira), no Cerro da Vila (Quarteira), no Montinho das Laranjeiras (Alcoutim), onde se encontram materiais muçulmanos. Mas, no caso do Montinho das 
Laranjeiras, a villa deixou de ser villa e transformou-se num monasterium (MACIEL, 1996: 99). Este foi, aliás, também o destino de S. Cucufate.

Se, na zona de Serpa, parece observar-se persistência dos fundi, diferente é o panorama da área ocidental do concelho da Vidigueira. A concentração de propriedade parece hipótese necessária para explicar a riqueza da pars urbana de S. Cucufate. Um fundus de 200 hectares, como seria o da villa do séc. I, não se afigura suficiente para justificar a magnificência do edifício áulico do séc. IV. Terá o proprietário de $\mathrm{S}$. Cucufate adquirido outras villael $\mathrm{E}$, neste caso, seriam estas contíguas ou dispersas? E quando terá começado esse fenómeno de concentração da propriedade?

Segundo Sillières e Mantas (in ALARCÃO, ÉTIENNE e MAYET, 1990), na área que prospectaram do concelho da Vidigueira, parece verificar-se o abandono de certos estabelecimentos rurais no fim do séc. I ou nos inícios do séc. II: villa da Boa Vista, granjas da Courela das Antas, Apariça e Choupanas. Poderemos ter aqui um indício de uma primeira concentração da propriedade. Pela sua proximidade, a villa da Boa Vista e a granja da Courela das Antas podem ter sido absorvidas por S. Cucufate, que teria mais do que duplicado a área do fundus.

O fenómeno de concentração da propriedade é atribuído por muitos ao Baixo Império. Mas, como se vê, nestes casos da Vidigueira e de Serpa, a informação é contraditória: a concentração parece ter-se verificado num lado mas não se observa no outro. A diversidade é tanto mais surpreendente quanto é certo que se passa no interior da mesma civitas, a de Pax Mia. De qualquer forma, e sem prejuízo de eventual desenvolvimento no Baixo Império, o fenómeno concentracionista parece ter-se dado, na Vidigueira, já nos fins do séc. I d.C.

Para as villae que duraram do séc. I ao $\mathrm{V}$, parece difícil admitir a permanência sem reconstruções profundas em dados momentos. Em S. Cucufate, a villa de meados do séc. I foi totalmente reconstruída no segundo terço do séc. II d.C.; e este edifício foi demolido para dar lugar a outro, de planta totalmente nova, c. 360 d.C. Possivelmente, a maior parte das villae sofreu reconstruções profundas, que são também visíveis em Milreu e na villa Cardílio. Mas será que poderemos generalizar os momentos de remodelação detectados em S. Cucufate? A pergunta, por enquanto, só tem resposta parcial: se as construções ou grandes edificações do séc. IV são bem visíveis, as do séc. II não estão documentadas. Recorde-se todavia o testemunho dos tesouros monetários 
do Noroeste: “a ausência de depósitos com valores entre 500 e 10.000 HS, a partir de Hadrianus, poderá ser interpretada,se bem que com muitas reservas, como um indício de uma acentuação do fosso entre pobres e ricos ao longo do séc. II" (CENTENO, 1987: 180). Neste contexto, é possível um movimento de reconstrução no séc. II d.C.

\section{As igrejas na Alta Idade Média fazem as villas}

O termo villa, na documentação da Alta Idade Média, é um termo polissémico, isto é, aplicava-se “a realidades diversas e díspares" (LOPEZ ALSINA, 1986: 197). Podia designar uma aldeia com seus moradores, os quais explorariam pequenos prédios (hereditates) sobre os quais uns teriam domínio eminente, e outros, domínio meramente útil. Era a W//a-aldeia. Mas, segundo o medievalista compostelano, o termo villa aplicava-se também a uma propriedade senhorial do tipo carolingio.

Nesta, o dominus reservava uma porção para exploração directa (porção que, na Baixa Idade Média, se chamava granja) e dividia o resto em parcelas onde instalava colonos, os quais, para além das rendas que pagavam, deviam dias de trabalho que prestavam no amanho da parte reservada pelo dominus (LOPEZ ALSINA, 1988: 199 e 201).

Como exemplo de v///a-aldeia, dá Lopez Alsina (1988: 202) a villa qui ab antiquis vocitabatur Lentobre et nunc vocitatur Ostulata, nas margens do Tambre. Parece-nos um bom exemplo. Escapou ao autor o facto de Lentobre poder ser um antigo castro romanizado. Nome semelhante, Letiobri, está atestado epigraficamente em Braga, designando um castellum, isto é, um castro que sobreviveu à romanização (ALBERTOS FIRMAT, 1975: 33). A identificação villa = aldeia poderá ainda abonar-se com documentos referentes a Sobrado, os quais sempre falam de villa, excepto um, que qualifica Sobrado de vicus. Ora vicus, na documentação medieval, significa aldeia (LOPEZ ALSINA, 1988: 203, nota 293).

A posição de Lopez Alsina converge com a de García de Cortázar (1988: 31): "... se, numa fase historiográfica anterior, tendíamos a considerar a existência de villae de tipo que chamaríamos carolingio, hoje inclinamo-nos a pensar que quase todas elas eram, de facto, aldeias". E, noutro lugar, García de Cortázar (1986: 191) cita um documento de 952 em que o rei García Sánchez I de Pamplona doa ao mosteiro de Sán

Conimbriga, 37 (1998), 89-119 
Millan de la Cogolla a igreja de Santa Maria, situada iuxta vicum qui dicitur Villa Gundisalbi.

A equacionação villa = aldeia é hoje pacífica. Aliás, já em 1980 a defendíamos: "o termo villa é, nos documentos da Reconquista, manifestamente ambíguo; ora indica uma herdade, grande ou pequena, ora uma aldeia, ora ainda uma circunscrição administrativa, digamos, o equivalente a uma paróquia” (ALARCÃO, 1980: 177).

Desenvolvamos mais esta ideia da villa equivalente a paróquia, que carece de explicitação e correcção.

A villa da Reconquista podia ser uma unidade entre aldeia e o "território". Como unidade político-administrativa à frente da qual se achava um administrador ou tenens como esse Dídaco Gonçalves que Afonso Henriques nomeou para a terra de Lafões (L.R I, $\mathrm{n}^{\circ}$. 62), a terra ou territorium compreendia várias villas. Estas eram provavelmente o equivalente das actuais freguesias, isto é, unidades que integravam várias aldeias e/ou lugarejos e casais dispersos polarizados em tomo de uma igreja. É o que parece deduzir-se do doc. PMH, DC XIII, muito comentado desde Alberto Sampaio.

Coube a Carlos Alberto Ferreira de Almeida o mérito de ter identificado a villa Sancta Eulalia a que o documento, datado de 906, se refere (ALMEIDA, 1970). Ficava no concelho de Barcelos e corresponderia à actual freguesia de Rio Covo (Santa Eulália). Ainda que tenhamos dúvidas sobre essa exacta correspondência, o importante é que o autor definiu os limites da villa com bastante aproximação, pois encontrou, na microtoponímia actual, correspondência à toponímia medieval. Infelizmente, não acompanhou o seu estudo com uma carta; e uma vez que grande parte desses microtopónimos não figura na carta 1:25.000, não podemos, como gostaríamos, traçar com um mínimo de rigor os limites da villa medieval de Santa Eulália. Mas esta compreendia o lugar da Várzea (actualmente sede de freguesia), confinava a ocidente com Remelhe, vinha a sul até Vilar e confrontava com Silveiros; a oriente confinava com Moure e abrangia o lugar actual de Crujães. Ao todo, uns 800 hectares.

$\mathrm{Na}$ área assim definida, pode ter existido uma villa romana no lugar de Águas Santas. C.A. Ferreira de Almeida não parece admitir essa hipótese, mas tão só a de um santuário pagão. A existência de vestígios arqueológicos, designadamente alicerces, um lageado, tubos de barro, cerâmica de construção e sigillata clara do séc. IV d.C., viabiliza 
a hipótese de uma villa. Mas não nos parece verosímil que esta eventual villa romana tivesse 800 hectares, pois, como vimos, mesmo no Alentejo, as propriedades não atingiam essa superfície e ficavam-se, na generalidade, por 200 hectares.

A villa medieval de Santa Eulália teria, no seu perímetro, aldeias e casais. Aldeias seriam Siccariolo, Bustello e Villare Spasameli, que ficaram divididas por metades, uma para Nausto, bispo de Coimbra, outra para Sisnando, bispo de Iria. Mas, provavelmente, o agrum Kuruianes, o agrum de Felgaria, o agrum de molino sicco e o agro de figarias eram também aldeias. O topónimo agrum Kurianes conserva-se actualmente no nome da aldeia de Crujães. Não temos conhecimento de medievalista que, até agora, tenha proposto a hipótese de o termo ${ }^{44}$ agro" poder corresponder, na documentação do séc. $\mathrm{X}$, a uma aldeia. O sentido que os medievalistas dão a agro é o de gleba dedicada a cultura arvense (SAMPAIO, 1979: 84). Mas, no documento que analisamos, parece evidente que se dá o nome de agro a aldeias ou lugarejos, ainda que, mais uma vez, o termo seja polivalente. Com efeito, o agrum Veremudi ou o agro Argirizi são, provavelmente, prédios do tipo que mais tarde se chamará casal.

Em 906, portanto, a villa de Santa Eulália compreendia aldeias e casais dispersos, compondo uma unidade que Afonso III (866-909) teria dados aos bispos de Coimbra e de Iria, sem ter delimitado muito bem a parte de cada um. O documento é uma composição para definir claramente o que pertencia a cada bispo.

Observada a falta de correspondência entre uma eventual villa romana com sede em Águas Santas e a villa dos bispos Nausto e Sisnando, temos de responder a duas questões:

1. Quando é que se formou essa paisagem de aldeias e casais em Santa Eulália?

2. Quando e como foi a área convertida numa unidade que em 906 se chama villa e se reparte entre os bispos Nausto e Sisnando?

À primeira pergunta podemos responder: talvez já na época romana. Se, na área de Viseu, não são visíveis aldeias na época romana (ALARCÃO, 1996), elas existem no território de Chaves e na região de Leiria, como vimos. Isto não significa que todos os casais dispersos e todas as aldeias da villa medieval de Santa Eulália sejam de origem romana. Entre o domínio romano e o séc. X, a alguns casais podem 
ter-se acrescentado outros casais e a algumas aldeias, outras aldeias, num processo de progressivo adensamento da população.

À segunda pergunta é mais difícil responder. Observemos, em primeiro lugar, que em Santa Eulália há alodios, isto é, propriedades isentas de renda ou tributo: são os prédios que se mencionam sem se atribuírem nem a Nausto nem a Sisnando. Mas a maior parte das propriedades atribui-se a um ou outro dos bispos e muitas dividem-se pelos dois, metade para cada um.

Podemos imaginar dois cenários. Num, primeiro, o dominus romano ou o seu sucessor suévico terão integrado a área dos pontos de vista religioso e fiscal. Se efectivamente houve uma villa romana em Águas Santas, pode ter-se construído aí, em época tardo-romana ou suévica, uma igreja privada. O respectivo eclesiástico teria a cura animarum da área que se estendia até Várzea e Crujães. Os fiéis destes lugares demorariam cerca de 40 minutos para vir a Águas Santas. Por outro lado, o dominus romano ou suévico pode ter imposto rendas e serviços aos pequenos proprietários até então livres de servidões. Se a integração religiosa precedeu a fiscal ou vice-versa não saberemos dizê-lo. Talvez as duas tenham andado a par. Neste cenário forma-se uma unidade que em 906 se chama villa mas que ultrapassava de longe os limites da eventual antiga villa romana.

Num segundo cenário, a villa romana e as aldeias e casais da área teriam mantido até à Reconquista a sua independência. Teria sido Afonso III a constituir uma unidade, a que terá chamado villa, dando-a aos bispos de Coimbra e Iria.

Se, do caso de Santa Eulália, passarmos à generalidade do território, imaginaremos uma paisagem tardo-romana, suévica e visigotica de aldeias e casais, granjas e villae sem grande integração mas progressivamente polarizada pela fundação de igrejas, seculares ou monásticas. A igreja terá sido o elemento gerador da villa, talhando unidades discretas numa paisagem anteriormente contínua. A igreja, reunindo os fiéis dela, separou-os dos fregueses doutra igreja. Assim se constituíram territórios demarcados que fronteiravam pelas cumeadas dos montes, pelas ribeiras divaguantes ou entestavam nas carrárias antigas. Não chamemos ainda paróquias a esses territórios, porque alguns poderiam ter igrejas que não fossem paroquiais. De qualquer forma, os territórios tinham limites tão definidos quanto eram solidários os vizinhos. A esses territórios se dava o nome de villas.

Conimbriga, 37 (1998), 89-119 
As villas terão constituído referências de naturalidade e residência equivalentes aos castella do séc. I d.C. Neste século, se dois desconhecidos se encontravam e, no decurso da conversa, se identificavam, não diriam somente chamo-me Viriatus e eu, Accius, mas indicavam sua residência: vivo no castellum tal. Dizer-se natural de ou residente no castellum tal não significaria necessariamente ter nascido ou morar no aglomerado. O castellum tinha um território, como hoje ainda o tem a aldeia. Nesse território havia, para além do pequeno aglomerado que lhe presidia, alguns casais dispersos. $O$ indivíduo natural de ou residente em um casal identificar-se-ia pelo nome do castellum em cujo aro ou território se situava o casal.

No fim do séc. I d.C., a menção da origo através dos castella desaparece da epigrafia. Mas terá desaparecido de facto na linguagem do dia a dia? Quando alguém casava e queria indicar a outro donde é que sua mulher era natural, não diria do castellum tal ?

$\mathrm{Na}$ Reconquista, a villa, possivelmente, substituiu o castellum como referência de naturalidade ou residência, embora não tenhamos registo documental disso. A villa tinha na igreja, paroquial ou não, o seu elemento integrador e demarcador. Os vizinhos reunidos em tomo de uma igreja, isto é, numa villa, estavam unidos numa comunidade de nós que se opunha aos outros. Esta villa, humana colmeia, era esta terra desta gente; outra villa era outra terra, era outra gente. Diferentes eram os santos padroeiros que contíguas villas elegiam. De comum só tinham o céu, que se não deixa repartir.

Esta comunidade vilânica e sobretudo esta correlativa animadversão pelos outros estão bem expressos no documento do Liber Fidei publicado por Avelino de Jesus da Costa (1959, vol. II, doc. 41). Dizem cinco presbíteros que fundam a igreja de S. Mateus de Sumilhães (freg. de Oliveira, conc. de Vila Nova de Famalicão): nos ommes sine eramus ecclesia et aliis ab ecclesiis sepe fugati fummus et in maxima dispectione eramus et ministerium Dei multociens perdidimus et illa ecclesia in qua eramus non erat sub beneditione episcopi. Os presbíteros viviam numa igreja que não tinha a bênção episcopal e eram, talvez juntamente com os homens a quem prestariam assistência, escorraçados das igrejas vizinhas. Assim, resolveram edificar e dotar uma igreja que veio a ter a aprovação episcopal. Não temos aqui um exemplo de igreja que, não sendo paroquial, todavia existia e podia ser o polo organizador de uma villal $A$ fundação de igrejas polarizadoras pode ter-se dado nos séculos VII e VIII, acentuando-se nos séculos IX, X e

Conimbriga, 37 (1998), 89-119 
XI. A vinda de homens do Sul, eventualmente fugidos a perseguições religiosas, poderá ter contribuído para essa fundação. Recordemos os moçárabes Muzara e Zamora que instituem um mosteiro (baselico) na villa que tinham tomado de presúria em Lordosa (Penafiel) (PMH, DC. $\mathrm{n}^{\circ}$. 9, do ano 882). Noutros casos, a fundação de igrejas poderá ter sido de iniciativa episcopal, monacal ou até promovida pela população, como parece ter sido essa de Parada, na terra de Santa Maria, em 952 (citada por MATTOSO, 1992: 473).

A tese que subscrevemos é, pois, a de que as villas da Reconquista não correspondem a villae romanas, mas que são uma realidade totalmente diferente, e de que a igreja gerou a villa, cujos limites correspondiam ao da área de exercício da cura animarum.

Alguns documentos parecem contrariar a hipótese de equivalência entre a villa e a igreja. A villa tem, por vezes várias igrejas. E o caso da villa de Santa Comba, doada em 985 por Monio Gonçalves ao mosteiro de Lorvão (L.P., doc. 1), cum adjacendis suis villares cum suas ecclesias. Trata-se, aqui, de uma villa muito mais extensa do que as do Entre Douro e Minho. Os documentos 1 e 2 do Livro Preto citam as confrontações: a oriente, Gestosa e Treixedo; a norte, Alvarim; a poente, o rio Cris; a sul, o Dão. Cerca de 3.000 hectares, enquanto as villas de Entre Douro e Minho seriam inferiores a 1.000 hectares (como no caso de Santa Eulália) e algumas, a 200. A villa de Santa Comba, mais do que contrariar a nossa hipótese, exemplifica talvez um outro sentido da equívoca palavra villa : o de vasta propriedade contínua de um rico senhor, herdade demasiadamente ampla para ser designada por hereditas.

Também se poderia aduzir contra a nossa hipótese o documento PMH, D.C. 67, que menciona sete villas contíguas cujas posições relativas esquematizamos na fig. 13. Do Censual do Bispo D. Pedro (1064-1089/ 1091) deduz-se que Vila do Conde, Formariz, Argivai e Touguinha tinham, nessa data, igrejas paroquiais (COSTA, 1959, II: 1-3 e 15). As outras villas do doc. 67 (datado de 953) eram as seguintes: Euracini (Varzim), Quintanela e Anseriz. Em 1084-1089/1091 não tinham igrejas paroquiais. Mas poderá daqui concluir-se que em 953 não tinham nenhum tipo de igreja?

Que a villa tinha normalmente sua igreja sugere-o ainda o documento 73 do Livro Preto, que é um rol das villas do mosteiro de Vacariça, em 1064. Citam-se aí 21 villas: 9 cum sua ecclesia; 1 com um mosteiro. Duas (as de S. Cucufate e Santa Cristina), pelos nomes, deviam 
ter também suas igrejas. Outras, correspondentes a povoações modernas (Sangalhos, Cepins, Vimieira), não custa a crer que tivessem também, já nessa data, suas igrejas, até paroquiais. Assim, em 21 villas, temos 15 com igrejas seguras ou prováveis. Não as teriam as outras?

Muitas das villas foram, na Reconquista, apresuradas. Ainda que o termo presúria possa, em muitos casos, corresponder à apropriação de terras desertas, temos aqui, possivelmente, mais uma vez, um termo polissémico. O documento $\mathrm{PMH}$, DC. 656, de 1086, recorda as presúrias de Sesnando na região de Coimbra. Terão correspondido, todas elas, a ocupações de terras desertas? Não terão consistido, algumas delas, num simples talhar de villas numa área razoavelmente povoada?

A presúria corresponderia à atribuição de uma villa a um ou dois senhores; mas os documentos parecem recordar villas sem senhores. Em 936, os homens de Alquinitia e de Vila Cova (conc. de Penacova) procedem à delimitação das respectivas villas, na presença do conde Ximeno Dias (PMH, DC., $\mathrm{n}^{\circ}$. 42). Não temos aqui prova da existência de possuidor de villa. Mas, em 980, Gaudinas e sua mulher doam ao mosteiro de Lorvão metade da sua villa de Alquinitia onde está a igreja de S. Martinho. Entre 936 e 980, a villa foi tomada por alguém. Também em 976 (PMH, DC., $\mathrm{n}^{\circ}$. 118), os homens de Ferrariolos ( Ferreirinhos?, conc. Anadia), aparentemente 17 moradores, venderam ao mosteiro de Lorvão a sua villa. Também aqui não temos senhor de villa até ao tempo em que o mosteiro de Lorvão a recebeu e se apropriou dela.

$\mathrm{Na}$ opinião de Pallares Méndez e de Portela Silva (1975:99), a villa da Reconquista não é um território fixo, mas algo que, por virtude de heranças, doações, compras e trocas, está submetido a um processo de fragmentação ou, ao invés, de alargamento. Temos sérias reservas a esta doutrina. É certo que o direito de propriedade se podia fragmentar: a villa, hoje propriedade de um só, podia amanhã ser possuída por dois ou três coproprietários; mas, na generalidade, mantinham-se os limites da villa. A palavra villa tem pois, nos documentos da Reconquista, o sentido de aldeia mas também o de unidade territorial composta por aldeias e casais dispersos, polarizada em tomo de uma igreja; e talvez ainda o de vasta propriedade. Eventualmente, uma villa poderia não ter aldeias, mas só casais, como poderá ser o caso de Freixeno, que Odoário concede a sua irmã Trudilli, cum omnes suas heriditates (PMH, DC., $\mathrm{n}^{\circ}$. 14, datado de 907). A villa ficava entre o castro de Alvarelhos (freg. Alvarelhos, conc. Santo Tirso) e o castro de Boi (freg. Vairão, conc. Vila do Conde).

Conimbriga, 37 (1998), 89-119 
Mas estes sentidos talvez não esgotem o conteúdo de um termo polissémico. Poderia a villa designar um grande prédio de tipo carolingio? As reservas sobre a existência do modelo definido pelos historiadores dos fins do séc. XIX e apelidado de villa carolingia não podem deixar de ser tidas em consideração (vid., por exemplo, BANGE, 1984:530). Mas quando vemos um Olide Tedones dar 15 villas como dote a sua esposa Ausenda Gormiri (PMH, DC., $\mathrm{n}^{\circ}$. 56, do ano 946), ou um Gonçalo Luz ceder, também em dote, 38 villas a sua mulher Unisco (PMH, DC, $\mathrm{n}^{\circ}$. 591, do ano 1081), serão estas idênticas à de Santa Eulália, isto é, unidades com aldeias e casais dispersos? Serão villas carolíngias? Não serão antes, e simplesmente, o que hoje poderíamos chamar quintas?

Pontuemos final neste artigo, que já vai longo. Villae romanas e villas da Reconquista, elementos fundamentais da paisagem rural, põem-nos ainda muitos problemas; mas a visão de Alberto Sampaio fez a sua época e não pode mais defender-se.

\section{REFERÊNCIAS}

ALARCÃO, Jorge de, 1980: "Os problemas da origem e da sobrevivência das villae romanas do Norte do país", Actas do Seminário de Arqueologia do Noroeste peninsular, Guimarães, Vol. III: 171-179

ALARCÃO, Jorge de, 1990: Portugal, das origens à romanização (vol. I de Nova História de Portugal, dirigida, por Joel SERRÃO e A.H. de Oliveira MARQUES), Lisboa

ALARCÃO, Jorge de, 1996: "As origens do povoamento da região de Viseu", Conimbriga, 35: 5-35

ALARCÃO, Jorge de, 1997: "A tecnologia agrária romana", in ALARCÃO, Adília, Portugal romano. A exploração dos recursos naturais, Lisboa: 137-148

ALARCÃO, Jorge de; ETIENNE, Robert; MAYET, Françoise, 1990: Les villas romaines de São Cucufate (Portugal), Paris

ALMEIDA, Carlos Alberto Ferreira de, 1970: "Ainda o documento XIII dos Diplomatae e Chartae", Revista da Faculdade de Letras da Universidade do Porto - História, 1: 97-107

ALMEIDA, Fernando de e FERREIRA, O. da Veiga, 1968: "Uma formax lusitano- romana da Egitânia", O Arquéologo Português, 3a. Série, 2: 61-70

ALMEIDA, Fernando de, 1977: Ruinas de Idanha-a-Velha. Civitas Igaeditanorum. Egitânia, Lisboa

Conimbriga, 37 (1998), 89-119 
AMARAL, Luís Carlos, 1994: São Salvador de Grijó na segunda metade do séc. XIV. Estudo de gestão agrária, Lisboa

AMARAL, Paulo, 1993: O povoamento romano no vale superior do Tâmega, Porto (Tese de mestrado apresentada à Faculdade de Letras, policopiada)

BANGE, François, 1984: "Uager et la villa: structures du paysage et du peuplement dans la région mâconnaise à la fin du Haut Moyen Age (IXe -Xle siècles)", Annales. Économies, Sociétés, Civilizations, 39e année (3): 529-569

BERNARDES, João Pedro, 1996: A civitas de Collippo, Ponta Delgada (Tese apresentada na Universidade dos Açores, policopiada)

CELUZZA, M.-G. e FENTRESS, E., 1986: "L'occupation du sol dans Tager Cosanus et la vallée de $Y$ Albegna (Italie)", in La prospection archéologique: paysage et peuplement (Actes de la table ronde des 14 et 15 mai 1982, Paris, publiés sous la direction d'Alain Ferdière et d'Elisabeth Zadora - Rio), Paris: 111-120

COELHO, Maria Helena da Cruz, 1989: O Baixo Mondego nos finais da Idade Média. Lisboa

COSTA, Avelino de Jesus da, 1959: O Bispo D. Pedro e a organização da diocese de Braga, Coimbra

DIAS, Maria Manuela Alves, 1986: "Inscrição funerária de Casével (Castro Verde)", Ficheiro Epigráfico, 18, n`. 83

ETIENNE, Robert e GEORGES, J-G., 1979: "Apropos du latifundium. IL Vocabulaire et prospection archéologique", in Miscellanea in onore di Eugenio Manni, Roma: 891-904

GARCIA DE CORTÁZAR, José Angel, 1988: “La progression cristiana hasta el Duero. Repoblación y organización social del espacio en el valle del Duero en los siglos Vili a XII", in España. Al Andaluz, Sefarad: sintesis y nuevas perspectivas, Salamanca: 23-35

GARCIA DE CORTÁZAR, José Angel e RUIZ DE AGUIRRE, 1986: “Aldea y comunidad aldeana en la Rioja medieval: el caso de Villagonzalo (Badarán)", Príncipe de Viana, anejo 2, Homenaje a José María Laccarra, Pamplona, 191-211

GONÇALVES, Iria, 1989: O patrimonio do mosteiro de Alcobaça nos séculos XIV e $X V$, Lisboa

GORGES, Jean-Gérard, 1979: Les villas hispano-romaines, Paris HIPÓLITO, Mário de Castro Hipólito, 1960-61: "Dos tesouros de moedas romanas em Portugal", Conimbriga, 2-3: 1-166

KAHANE, Anne; THREIPLAND, Leslie Murray; WARD-PERKINS, John, 1968: "The ager Veientanus, north-east of Rome", Papers of the British School of Rome, 36

LEMA, Paula Bordalo, 1978: Tourém. Uma aldeia raiana do Barroso, Lisboa

L.P, Livro Preto, edição do Arquivo da Universidade de Coimbra, I, 1977

Conimbriga, 37 (1998), 89-119 
LOPES, Maria da Conceição; CARVALHO, Pedro e GOMES, Sofia, no prelo: Arqueologia do concelho de Serpa

LOPEZ ALSINA, Fernando, 1988: La ciudad de Santiago de Compostela en la Alta Edad Media, Santiago de Compostela

MACIEL, M. Justino, 1996: Antiguidade tardia e Paleocristianismo em Portugal, Lisboa

MANTAS, Vasco Gii, 1996: "Teledetecção, cidade e território: Pax Iulia”, Arquivo de Beja, 3a. série, 1: 5-30

MATTOSO, José, 1992: História de Portugal, vol. I: Antes de Portugal, Lisboa

PALLARES MÉNDEZ, Ma. C. e PORTELA SILVA, E., 1975: “Aproximación al estudio de las explotaciones agrarias en Galicia en los siglos IX-XII", Actas de las I Jomadas de Metodologia Aplicada de las Ciências Históricas, II Historia Medieval, Santiago de Compostela: 45-113

QUINTELA, Antonio de Carvalho; CARDOSO, João Luís; MASCARENHAS, José Manuel, 1995 "Barragens romanas do distrito de Castelo Branco e barragem de Alferrarede", Conimbriga, 34: 75-127

RIBEIRO, Orlando; LAUTENSACH, Hermann; DAVEAU, Suzanne, 1989: Geografia de Portugal. III. O povo português, Lisboa

RUIVO, José da Silva, 1995: Circulação monetária na Estremadura portuguesa até aos inícios do séc. III, Porto (Tese de mestrado apresentada à Faculdade de Letras, policopiada)

SAMPAIO, Alberto, 1979: Estudos históricos e económicos. As vilas do Norte de Portugal, Lisboa

SILVA, Armando Coelho Ferreira da, 1983: "As tesserae do Castro da Senhora da Saúde ou Monte Murado (Pedroso, V.N. Gaia). Contributo para o estudo das instituições e povoamento da Hispânia antiga", Gaya, 1: 9-26

SOUSA, Élvio Melim de, 1966: "Cerâmicas ditas campanienses e de imitação conservadas no Museu Regional de Sintra", Conimbriga, 35: 37-58

UNTERMANN, Jürgen, 1965: "Miscellaneas epigráficas-linguísticas", Archivo Español de Arqueologia, 38: 8-25

WAHL, Jürgen, 1985: "Castelo da Lousa, ein Wergehöft Caesarisch-Augusteicher Zeit", Madrider Mitteilungen, 26: 149-176

Conimbriga, 37 (1998), 89-119 


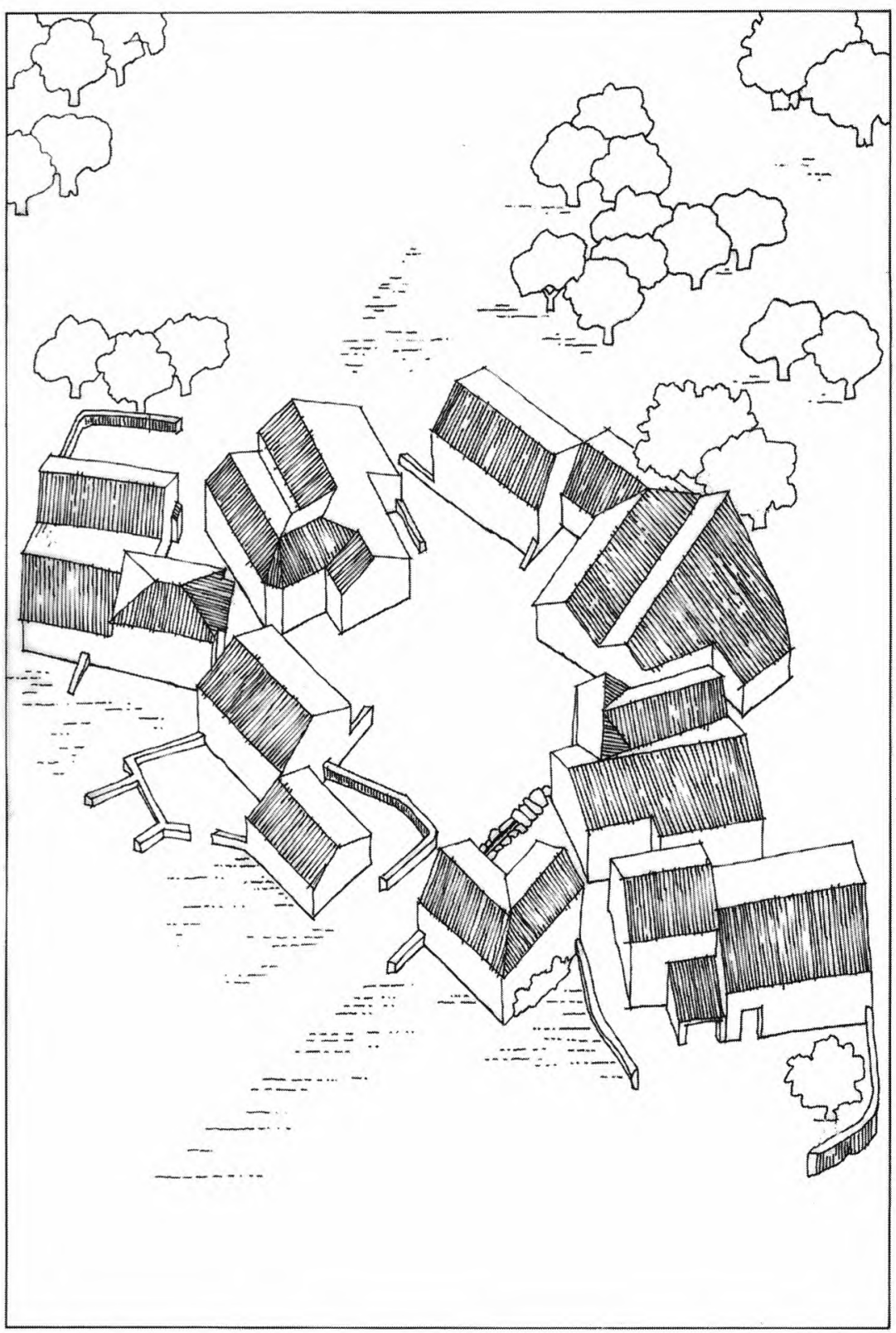

Representação de uma aldeia 


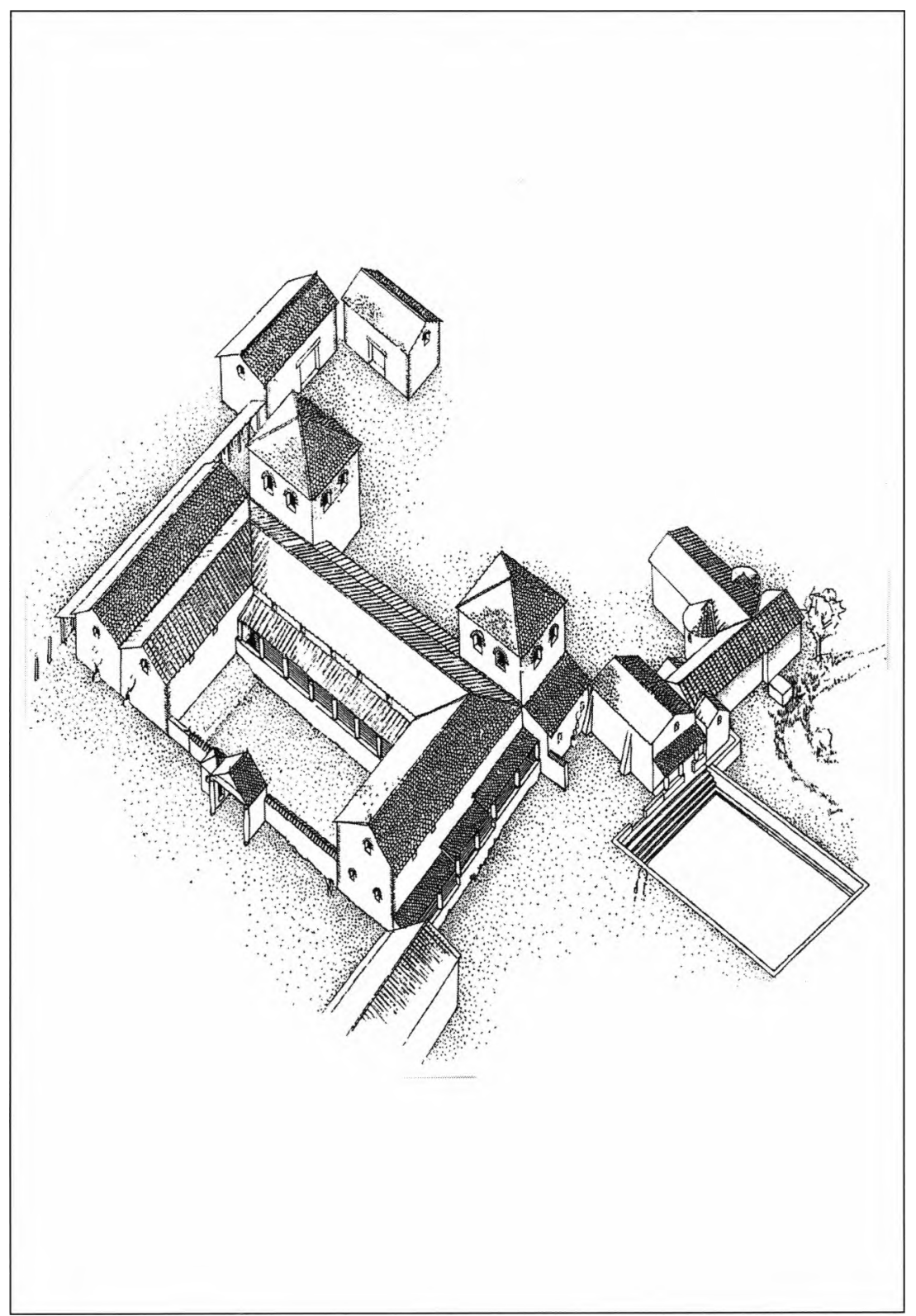

Pars urbana de uma villa, segundo David S. Neal, The excavation of the Roman villa in Gadebridge Park, Hemel Hampstead, 1963-8, Londres, The Society of Antiquitaries, 1974 
Est. III

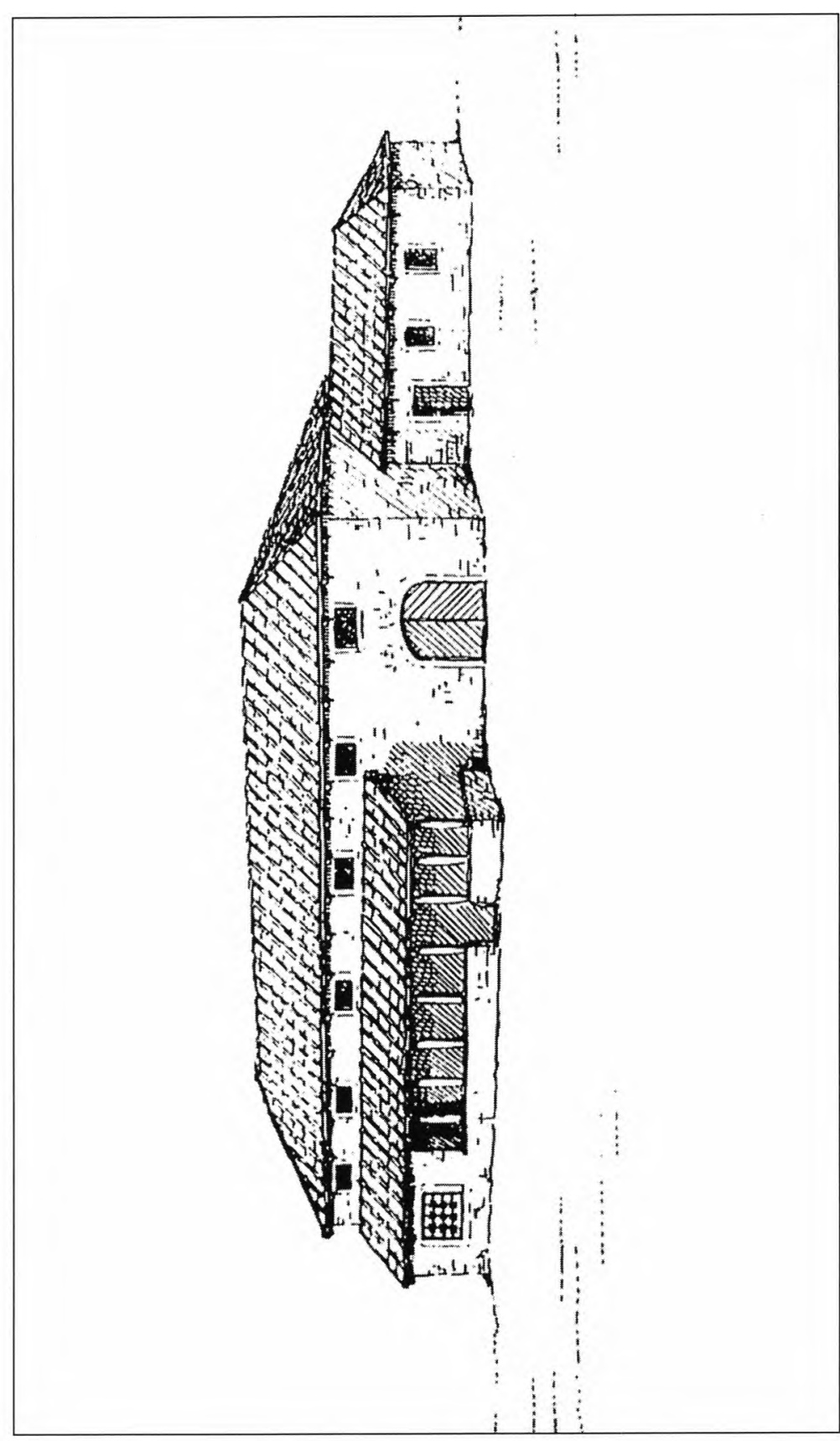

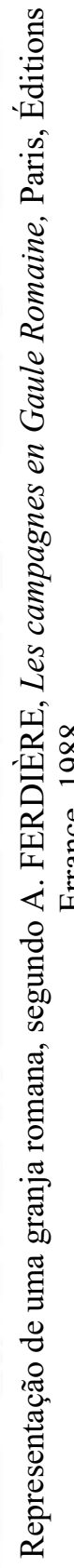



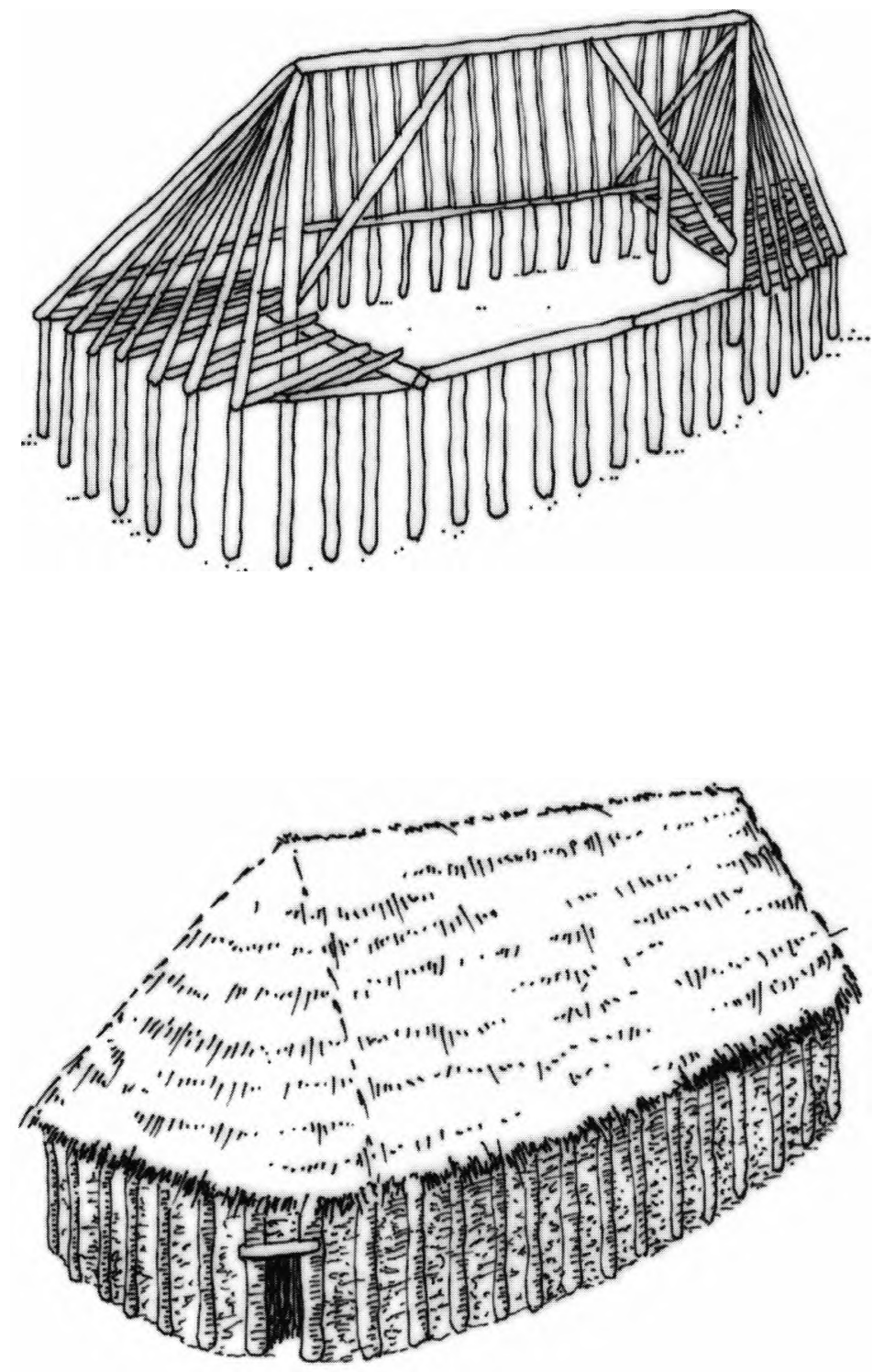

Representação do que César designava por aedificium 
EsT. V

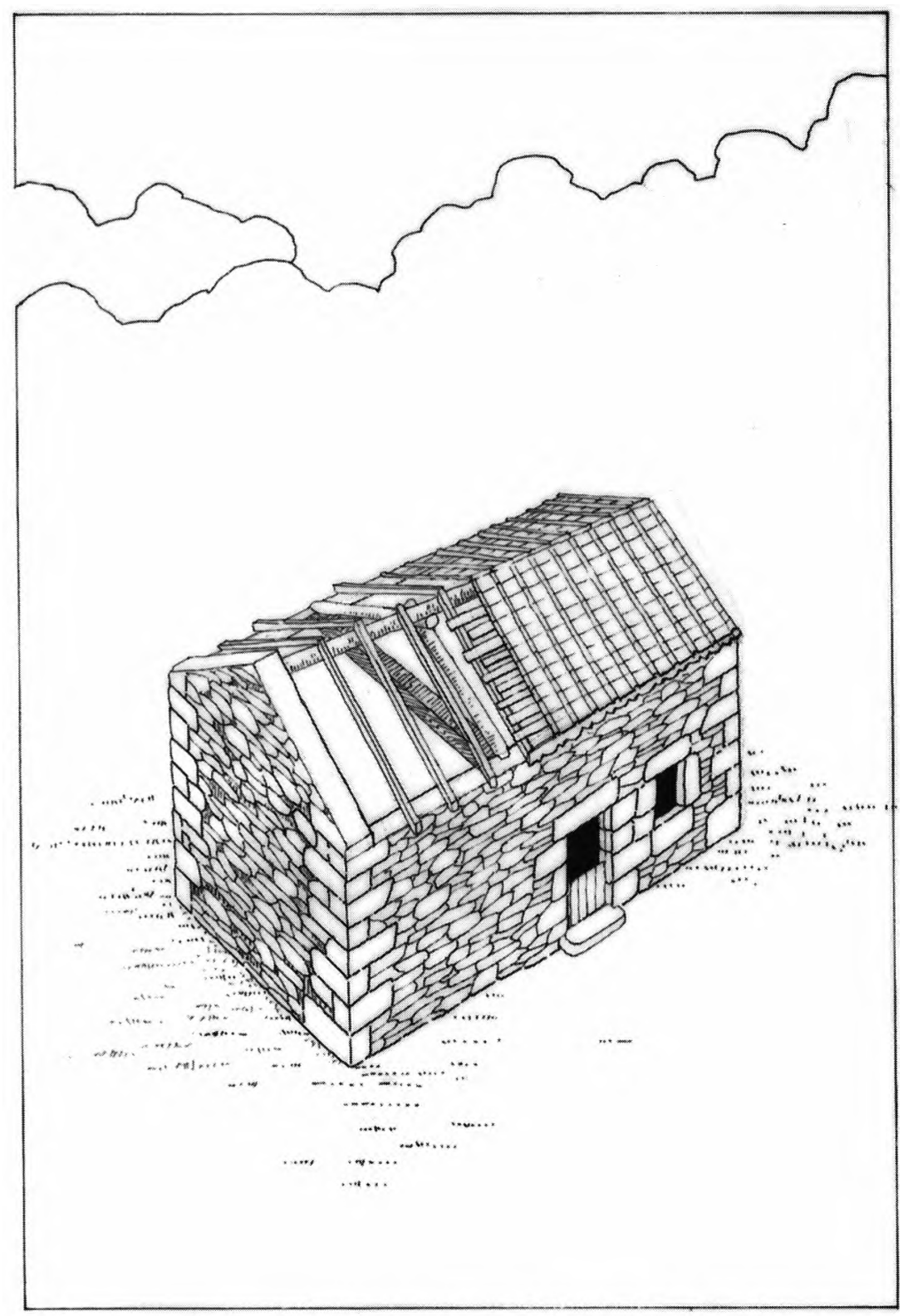

Representação de um casal romano 


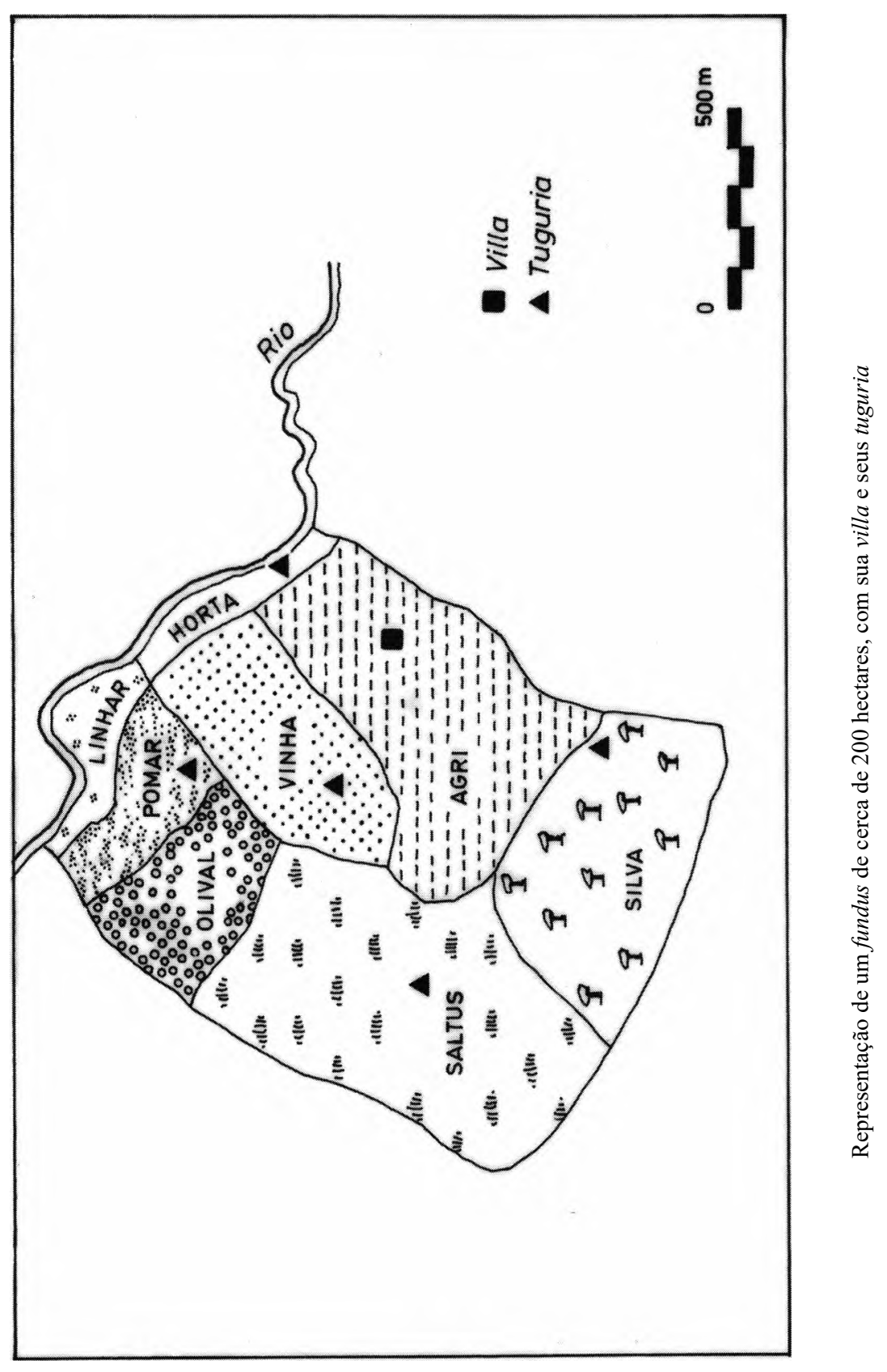




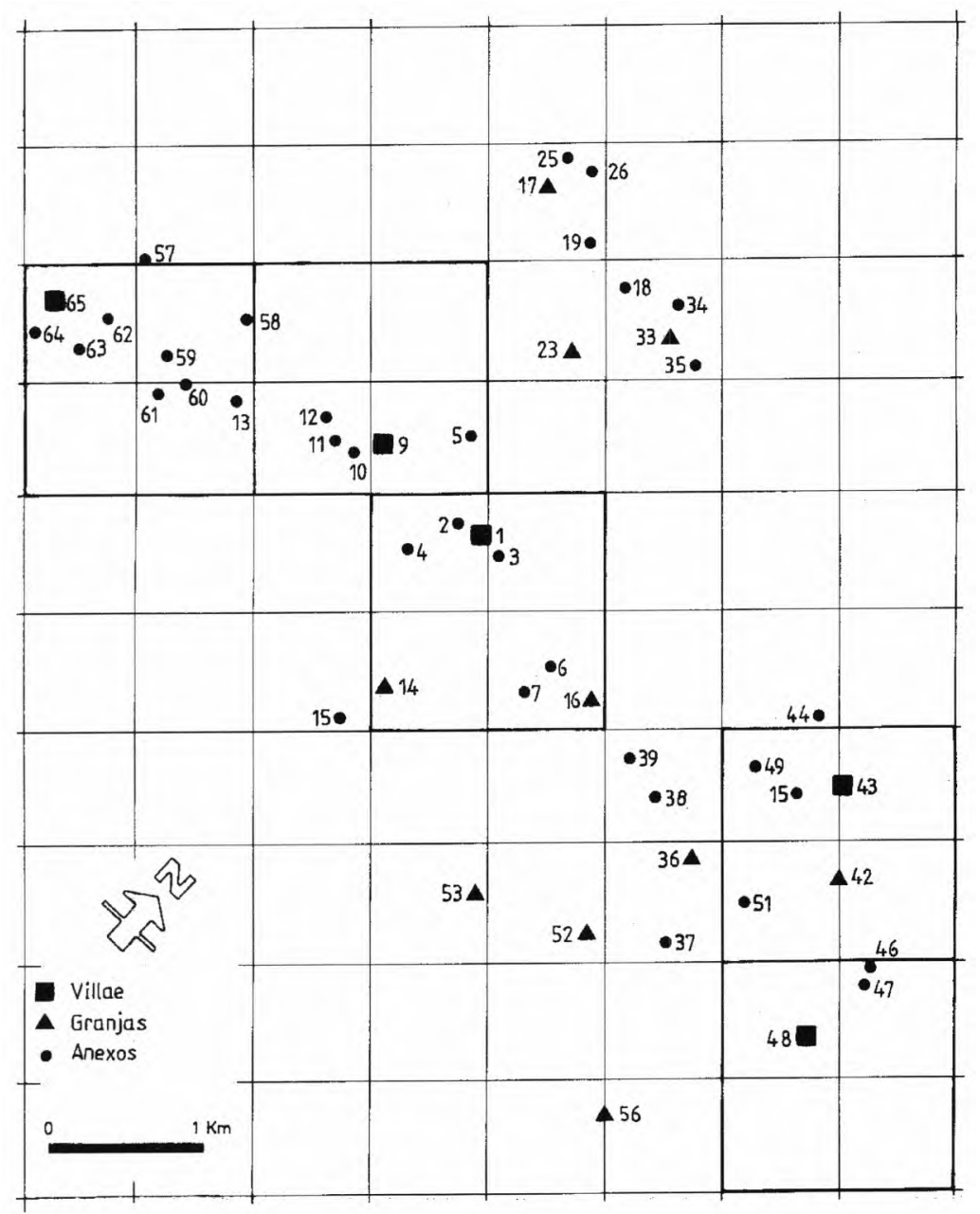

Ocupação romana na área de S. Cucufate (Vidigueira) 


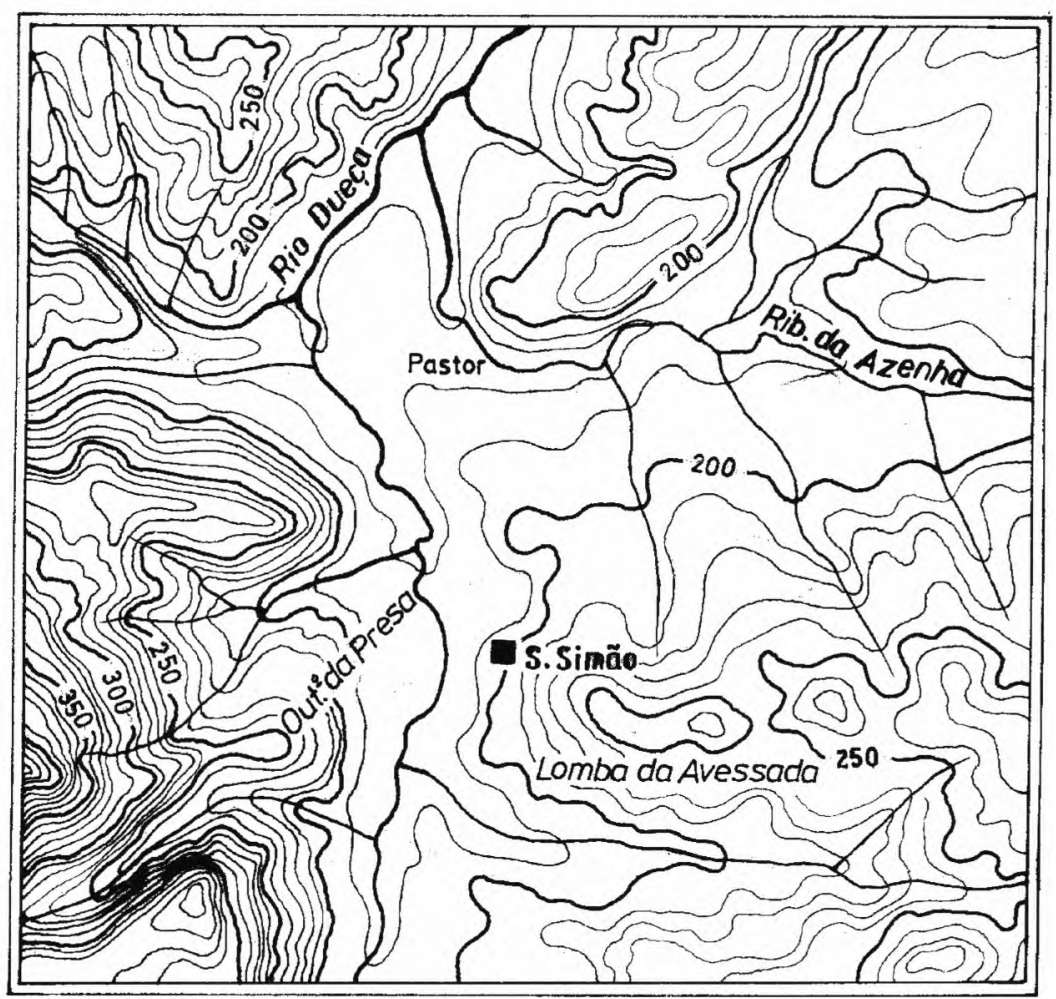

Carta Militar de Portugal / Serviços Cartográficos do Exército, folha 263 (Espinhal/ Penela) 1947/esc. 1/25.000

Fundus da villa de S. Simão 
EST. IX

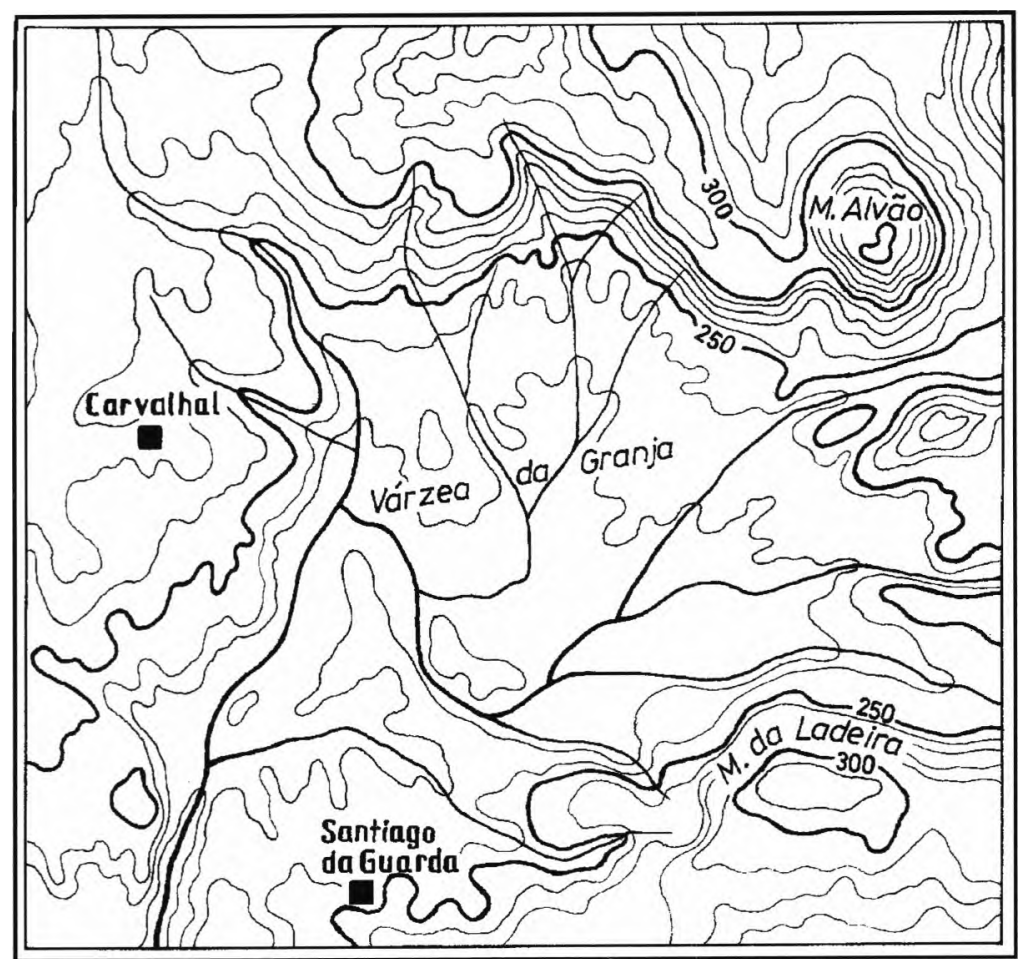

Carta Militar de Portugal / Serviços Cartográficos do Exército, folha 263 (Espinhal/ Penela) $1947 /$ esc. $1 / 25.000$

Fundi das villae de Carvalhal e Santiago da Guarda 


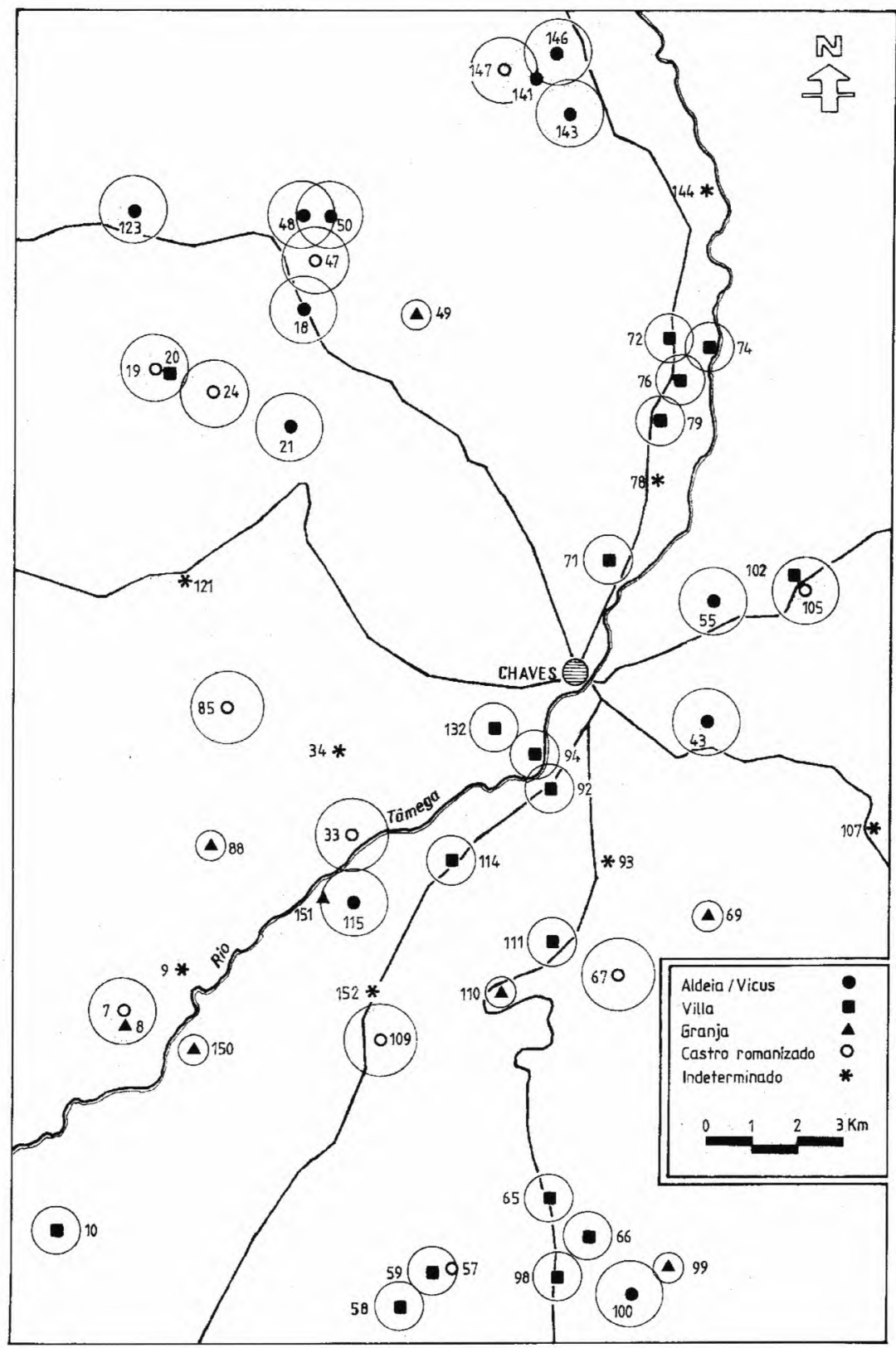

Ocupação romana na área de Chaves 
EsT. XI

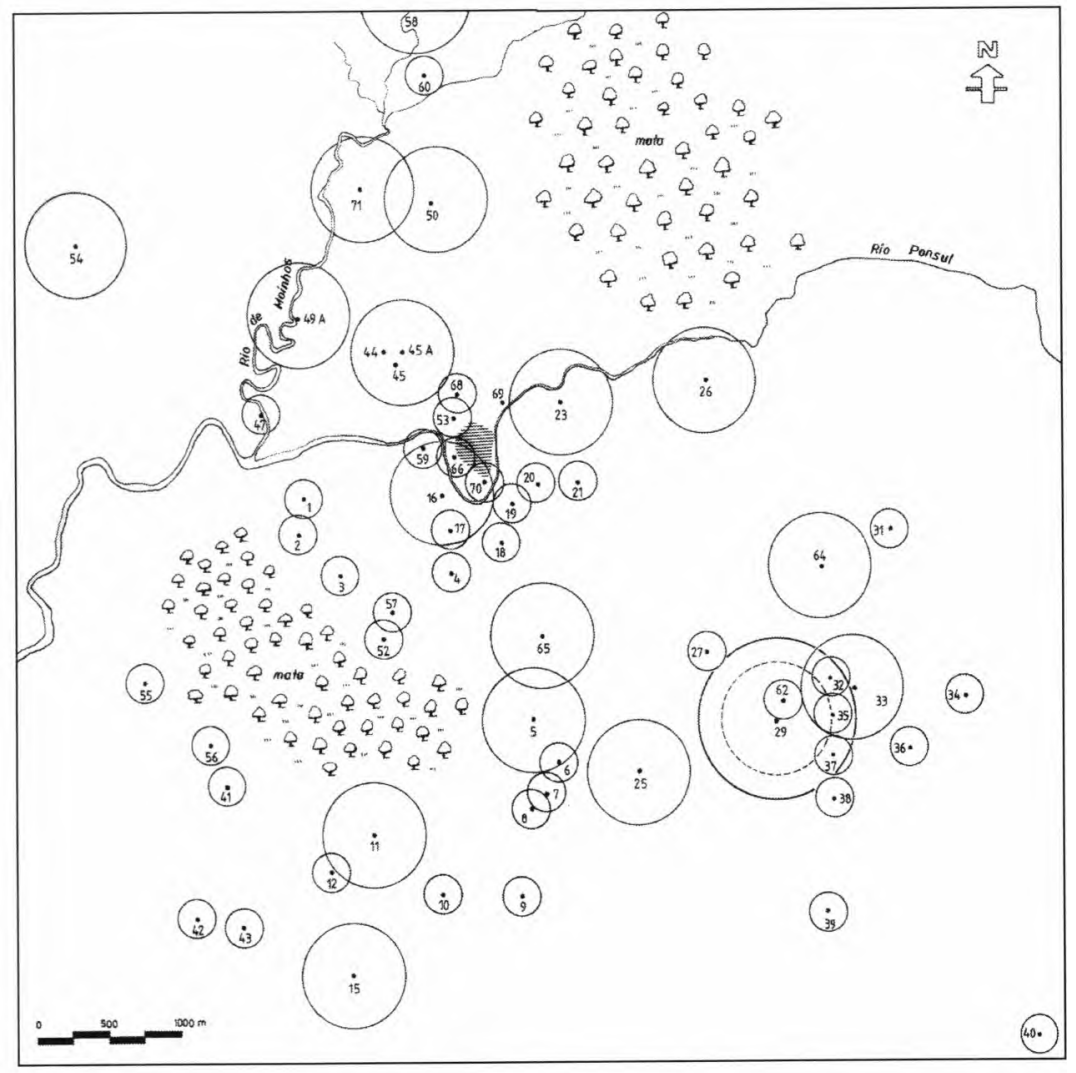

Ocupação romana na área de Idanha-a-Velha (Egitânia) 


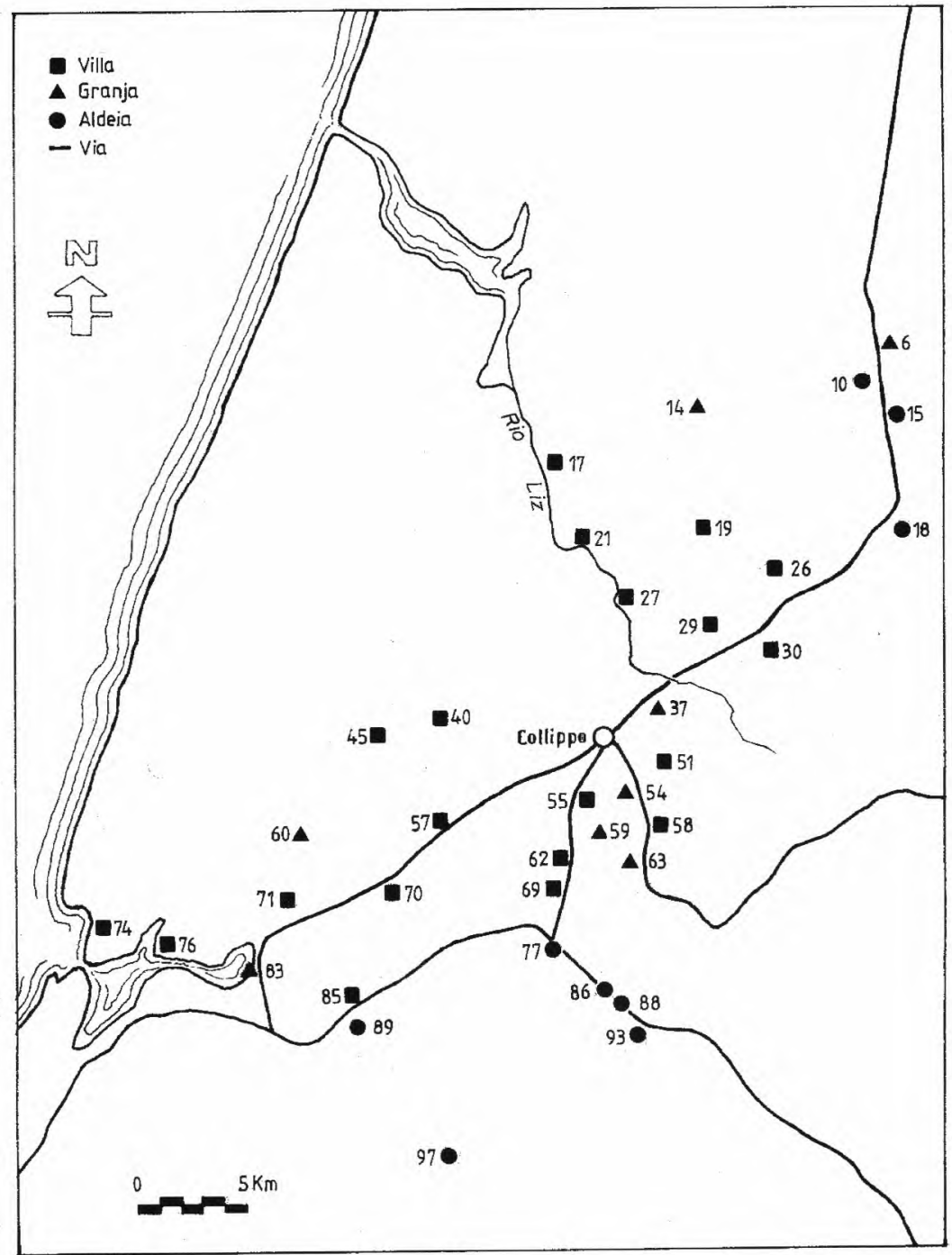

Ocupação romana na área de Collippo 
EST. XIII

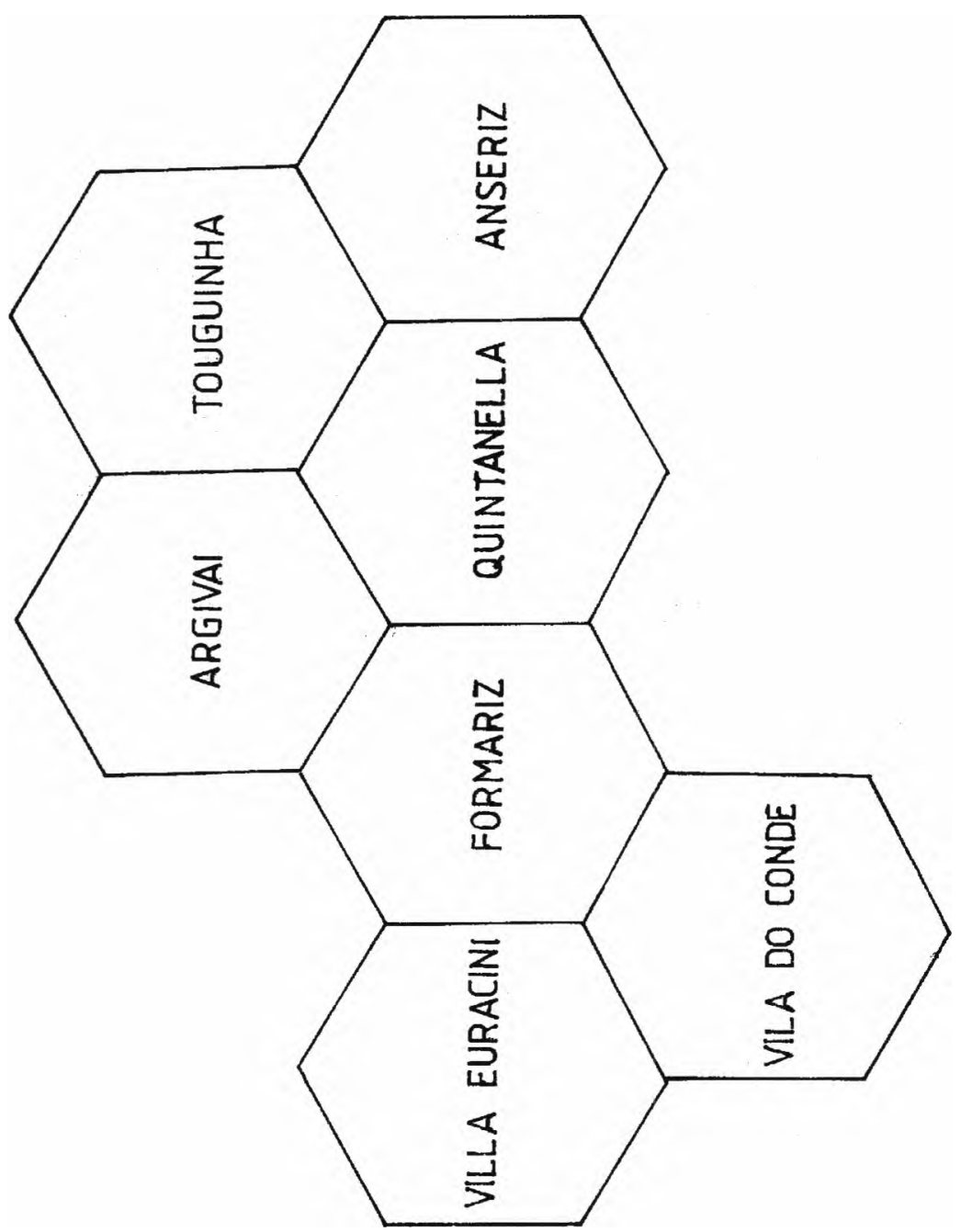

As villas mencionadas em PMH, D.C. 67 